\title{
1834 VE 1840/41 TARİHLİ NÜFUS DEFTERLERİNE GÖRE KARASINIR VE ELMASUN (GÜNEYSINIR)*
}

\section{KARASINIR AND ELMASUN (GUNEYSINIR) ACCORDING TO 1834 AND 1840/41 DATED REGISTER BOOKS}

\author{
Hüseyin MUŞMAL ${ }^{* *}$ \\ Mehmet ÖZÇELIK ${ }^{* * *}$
}

\begin{abstract}
$\ddot{O} z$
Günümüzde Konya ilinin Güneysınır ilçesinin merkez mahallelerini oluşturan Karasınır ve Elmasun, Osmanlı Devleti döneminde Konya Vilayeti'nin Belviran Kazası'na bağlı köyler idi. Bu iki yerleşim yerinin bağh bulunduğu idarî birim olan Belviran Kazası'na ait 1834 ve 1840/41 tarihli nüfus defterleri, Türkiye Cumhuriyeti Başbakanlık Devlet Arşivleri Genel Müdürlüğ̈̈ Osmanl Arşivleri Daire Başkanlığında BOA, NFS.d katalogunda sırasılyla 3373 ve 3374 numarada kayıtlıdır. 1834 yılına ait 3373 numaral defter, sayfa usûlü numaralandırılmış olup toplam 67 sayfadan oluşmaktadır. Defterle ilgili bilgi formunda verilen bilgilere göre, defterin başlangıç tarihi 27 Şubat 1834'tür. 1840/41 yıllarına ait 3374 numaralı Belviran Kazası Nüfus Defteri ise varak usûlü numaralandırılmış olup 224 sayfadan oluşmaktadır. Her iki defterde de nüfus kayıtları hane esasına göre tutulmuştur. Nüfus verilerinin kaydedilmesinde hane reisi esas alınmış, ilk olarak hane reisi yazıldiktan sonra sırayla o hanede yaşayan erkek nüfus kaydedilmiştir. Defterlerde kadın nüfusa dair herhangi bir kayıt bulunmamaktadır. Çalışmamıza konu olan nüfus defterleri, Karasınır ve Elmasun'da yaşayan erkek nüfusun, isim, baba ismi, lakap, yaş ve eşkal bilgilerini ihtiva etmektedir. Dolayısıyla çalışmamızda, 1834 ve 1840/41 yıllarına ait nüfus defterlerindeki verilerin değerlendirilmesi suretiyle XIX. yüzyılın ikinci çeyreğinde Karasınır ve Elmasun köylerinin demografik yapısı, sosyal ve kültürel özellikleri ele alınacaktır.
\end{abstract}

Anahtar Kelimeler

Karasını, Elmasun, Belviran, Nüfus Defteri, XIX. Yüzyıl.

\begin{abstract}
Karasinir and Elmasun, which are the central neighborhoods of southborder district of Konya province at the present time,were the villages connectod to Belviran township of Konya province during the Ottoman period. 1834 and 1840/41 dated register books belonging to Belviran township which is the administrative unit of these two settlements are registered in no 3373 and 3374 respectively, in BOA, NFS.d catalogs at Department of Ottoman Archives of General Directorate of State Archives of Republic of Turkey Prime Ministry. 3373 numbered book concerning the year 1834
\end{abstract}

\footnotetext{
Bu çalışma, Prof. Dr. Hüseyin MUŞMAL'ın danışmanlığında, S. Ü. Sosyal Bilimler Enstitüsü Yeniçağ Tarihi Ana Bilim Dalında Yüksek Lisans Öğrencisi Mehmet ÖZÇELIK tarafından hazırlanmış olan "H.17 Şevval 1249 (M.27 Şubat 1834) ve H.1256 (M. 1840-41) Tarihli Nüfus Defterlerine Göre Karasınır ve Elmasun” isimli yüksek lisans seminerinin genişletilmesiyle oluşturulmuştur.

** Prof. Dr., Karamanoğlu Mehmet Bey Üniversitesi Edebiyat Fakültesi Tarih Bölümü, El-mek: hmusmal@hotmail.com

*** Selçuk Üniversitesi SBE Yeniçağ Tarihi Ana Bilim Dalı Yüksek Lisans Öğrencisi, El-mek: ozcelikmehmett@hotmail.com
} 
is enumerated according to the procedure of page, and consists of 67 pages in total. According to the information given in the information form of the book, the starting date of the book is 27 February 1834. 3374 numbered book concerning the year 1840/41 is enumerated according to the procedure of folio, and consists of 224 pages in total. The registers at both books are kept on the basis of household. Household head was based on on the registration of population data. First, household head was recorded, and then the male population living in that household were recorded. There is no record of women population in the books. The register books, the subject to our study, contain the names, father names, nicknames, ages and appearance data of the male population living in Karasinir and Elmasun. Accordingly, in our study, the demographic structures, social and cultural characteristics of Karasinir and Elmasun villages in the second quarter of the IX th century will be discussed by evaluating the data in the population books of the year 1834 and 1840/41.

\section{Keywords}

Karasinir, Elmasun, Belviran, Register Book, XIX. Century. 


\section{GíRIŞ}

Nüfus kelimesi, köken itibariyle Arapça bir kelime olup, nefs kelimesinin çoğuludur ve "ruhlar, canlar, hayat" gibi anlamlara gelmektedir (Devellioğlu 2000: 818). "Bir yerde oturan, ikamet eden" anlamına gelen ve sakin kelimesinin çoğulu sükkan/sekene kelimeleri de nüfus kelimesinin karşılığında kullanılmaktadır (Bozkurt 2007: 293). Nüfus, günümüzde taşıdığ1 anlamına göre ise kısaca, sınırları belli bir alanda ve belli bir zamanda yaşayan insan sayısı olarak tanımlanabilir. Bu alan, yeryüzü üzerindeki bölge, bir köy, bir kasaba, bir kent, hatta bir kıta gibi değişik yerleşim birimleri şeklinde olabilir (Gürtan 1969: 4-5).

Tarihte ilk kez hane kayıtlarının tutulmasıyla başlayan nüfus hizmetleri çok eski bir geçmişe sahiptir. Yüzyıllar boyunca ülkeler doğum, ölüm ve evlenme gibi nüfus olaylarını ve nüfus hareketlerini, genellikle askerlik ve vergi toplama amaciyla kayıt altına almaya çalışmışlardır. Osmanlı Devleti de toplumu idare etmek ve çeşitli politikalar üretebilmek, hazineye gelir sağlamak, asker ve vergi toplamak gibi çeşitli amaçlarla nüfus verilerine ihtiyaç duymuştur. Bu nedenle devlet, klasik dönemden itibaren arazi ve nüfus sayımı yapılmasına ve bunlarla ilgili kayıtların tutulmasına özel bir önem vermiştir (Çimen 2012: 185). Bu çerçevede Osmanlılar klasik dönemde arazi tahrirleri, modern dönemde ise nüfus tahrirleri gerçekleştirmişlerdir (Uslucan 2012: 2). Dolayısıyla Türkiye açısından nüfus hizmetleri, Osmanlı Devleti döneminde ortaya çıan güçlü ve köklü geleneklere dayanmaktadır (Çimen 2012: 185).

Çalışmamızda da Osmanlı Devleti'nde 1834 ve 1840/41 yıllarında yapılan nüfus sayımları sonucu ortaya çıkan defterlere göre Karasınır ve Elmasun köyleri ele alınacaktır. Ancak araştırma konumuzun detaylarına geçmeden önce, Osmanlı Devleti'nde yukarıda bahsedilen klasik ve modern dönemdeki nüfus ve arazi sayımlarının geçirdiği tarihî süreç incelenecek bununla birlikte Karasınır ve Elmasun köylerinin Osmanlı'dan Türkiye Cumhuriyeti'ne uzanan dönemde idarî statülerinde geçirdikleri dönüşüm kısaca ele alınacaktır. Daha sonra ise araştırmamızın ana kısmına geçilerek, nüfus defterlerinden elde edilen veriler vasıtasıyla Karasınır ve Elmasun'un demografik yapısı, sosyal ve kültürel özellikleri ile ilgili bazı değerlendirmeler yapılacaktır.

\section{OSMANLI'DA NÜFUS SAYIMI GELENEĞİ}

Osmanlı Devleti, daha erken zamanlarından itibaren fethedilen bölgelerde, öncelikle nüfus ve arazi tahriri yapmaktaydı (Gül 2015: 158). Başlangıçta Osmanlı tahrirlerinin amacı, imparatorluğun toplam nüfusunu ve nüfus özelliklerini kaydetmek gibi istatistikî amaca yönelik değildi. XV-XVI. yüzyıllardaki tahrirler, yetişkin erkekleri, özellikle vergi ödeyen kişi olarak hane reisiyle birlikte bekârları ve diğerlerini içeriyordu (Karpat 2003: 46). Her ne kadar tahrir defterleri hazırlandığı dönemin nüfusuna ait bazı verileri içeriyorsa da, bu verilere günümüz anlayışına uygun nüfus sayımı demek mümkün değildir (Gül 2015: 158). Çünkü tahrirlerde nüfusun büyük bir bölümü olan kadınlar, çocuklar, askerîler çeşitli sebeplerden dolayı kayıt dışı tutulmuştur (Öz 2000: 20). 1831 yılında ise modern anlamda nüfus sayımlarına adım atılmıştır. Bu tarihten itibaren devlet genelinde çeşitli bölgesel ve genel sayımlar yapılmıştır. Böylece arazi ve nüfus tahrirleri şeklinde Osmanlı'nın kuruluş yıllarından itibaren devam eden bu sayım ve yazım geleneği, dönemlere göre çeşitli aşamalardan ve değişikliklerden geçerek Cumhuriyet dönemine kadar devam etmiştir (Çimen 2012: 183-185).

Dünyada çağdaş anlamda nüfus hizmetleriyle ilgili köklü çalışmalar, 1790 yılında Amerika 
Birleşik Devletleri, 1801 yılında Fransa ve Britanya'da yapılan nüfus sayımlarıyla başlamıştır. Nitekim XIX. yüzyılda düzensiz de olsa dünya ülkelerinin çoğunda geniş kapsamlı sayımlar yapıldığı görülmektedir. Osmanlı Devleti'nde ise ilk nüfus sayımı 1831 yılında yapılmıştır. Bu yüzden 1831 senesinde yapılan nüfus sayımı nüfus hizmetleri tarihi bakımından milat sayılmaktadır (Çimen 2012: 193-194).

1831 tarihli nüfus sayımının en önemli sebepleri, 1826 yılında Yeniçeri Ocağı kaldırıldıktan sonra yeni kurulan Asâkir-i Mansûre-i Muhammediyye adı verilen ordunun asker ihtiyacının karşılanması, vergilerin toplanmasında görülen aksaklıkların düzeltilmesi ile cizye alınabilecek gayrimüslim nüfusun tespit edilmesi olarak ifade edilebilir (Çimen 2012: 193-194). Bu dönemde bir süredir devam eden savaşlar yüzünden vergi düzeni bozulmuştu. Zengin Müslüman ve Hıristiyanlar, ödemekle mükellef oldukları verginin üçte birini veya yarısını ödediği gibi himaye ve iltimaslar sebebiyle hiç vergi ödemeyenler de vardı. Ayrıca Anadolu'da bazı bölgelerde köprü, han tamiratı ve derbent muhafızlığı karşılığı bazı köylere vergi afları verilmişti. Fakat zamanla söz konusu mimarî yapıların yıkılmalarına rağmen halk aynı muafiyetten yararlanıyordu ve bu karyelerin vereceği vergi miktarı ise diğer karyelere yükletiliyordu. Bu adaletsizliklere karşı devlet müdahale etmeye çalışmasına rağmen, uzun süren savaşlar yüzünden bu durumla etkin bir şekilde ilgilenilememişti. İşte bütün bu sebepler nüfus sayımını zorunlu kılıyordu (Karal 1997: 10-11).

Planlanan nüfus sayımı esasen 1828-1829 tarihinde yapılmaya çalışılmış ancak 1828-1829 yılında Osmanlı-Rus Savaşı'nın başlamasıyla sayım sadece İstanbul'da yapılabilmiş, ülke genelinde uygulanamamıştır (Muşmal-Şahinkaya 2015: 483). Böylece savaştan sonra sayım için bütün hazırlıkları tamamlanmış ve 1830 yılında nüfus sayımına başlanmıştır. Ancak sayım devletin her bölgesinde aynı zamanda tamamlanamamıştır. Bazı bölgelerde sayım 1831 yılında bitirilebilmiştir (Kütükoğlu 2010: 3-4). Modern anlamda ilk genel nüfus sayımı ile ilgili kaynaklarda, sayımın 1830 veya 1831'de yapıldığına dair iki farklı tarihin olması bu sebepten kaynaklanmaktadır.

1831 yılı sayımı, Mısır, Arabistan, Arnavutluk, Bosna ve Güneydoğu Anadolu dışında ülke genelini kapsaması ${ }^{1}$ açısından (Çimen 2012: 194-195) ve toprak yazımı vesilesi olmadan doğrudan doğruya nüfusun tespiti için yapılan ilk sayım olarak kabul edilmektedir (Karal 1997: 10). Müslüman nüfusun askerî potansiyelini öğrenmek ve gayrimüslim reayadan vergi toplamak amacıyla yapıldığı için de, bu sayımda kadın nüfus sayılmayıp sadece erkek nüfus kaydedilmiştir. Çünkü askere alınabilecek olan sadece Müslüman nüfustur. Bunun yanısıra cizye ve bedel-i askeriye vergisine tabi gayrimüslim nüfus da reaya, Ermeni, Yahudi, Kıpti şeklinde tasnif olunmuştur (Behar 2000: 68). 1831 sayımına ait defterler, bazı eksiklik ve sorunlarına rağmen ülkede yaşayan Müslüman ve gayrimüslim erkek sayısı, yaşları, meslekleri ve eşkâlleri ile ilgili bilgiler vermesi açısından önemlidir. Ayrıca 1831 sayımı öncesi ve sonrasında yapılan bazı düzenlemeler ve çıkartılan nizamnameler, ülkede merkezî bir nüfus kayıt sisteminin kurulmasını ve nüfus değişikliklerinin ve hareketlerinin düzenli olarak takip edilmesini sağlamıştır (Akyel-Sertel 2015: 81).

Osmanlı Devleti'nde yapılan nüfus sayımları sadece 1831 yılındaki sayımla sınırlı kalmamıştır. Osmanlı Devleti, 1831 senesine ait nüfus verilerini adeta bir veri tabanı olarak kullanmış ve üç-beş yılda bir nüfus güncellemesi yaptırmıştır. Zamanla değişen koşullar, yeni getirilen düzenlemeler, 1831 yılında yapılan sayımların daha sonra ortaya çıan eksik yönleri, imparatorluktaki bireylerin tamamının sayıma tabi tutulmamış olması gibi nedenler sonraki

1831 yılına ait sayımda Anadolu'da ve Rumeli'de sayım yapılan bölgeler için bkz. (Karal 1997: 13-17) . 
dönemlerde yeni nüfus sayımlarının yapılmasını zorunlu kılmıştır (Muşmal-Ürekli: 2-3). Böylece 1831 yılı genel nüfus sayımı ve sonrasında Dâhiliye Nezareti bünyesinde Ceride-i Nüfus Nezareti ve sancaklarda defter nazırlıklarının kurulmasıyla başlayan modern nüfus hizmetlerinden sonra 1844, 1852, 1856, 1866, 1881/82 ve 1905 gibi değişik tarihlerde bölgesel veya genel nüfus sayımları yapılarak, kayıtların güncel tutulmasına çalışılmıştır (Çimen 2012: 183).

\section{KARASINIR VE ELMASUN'UN İDARÎ YAPISI}

Karasınır ve Elmasun (Güneybağ), günümüzde Konya ili Güneysınır ilçesinin merkez

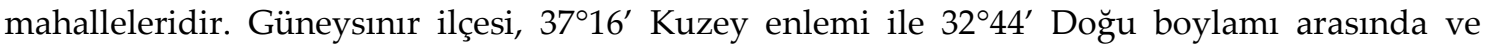
Konya il merkezinin 87 km güneyinde, Karaman'ın 44 km batısında yer alır. İlçenin kuzeyinde Çumra, güneyinde Hadim, batısında Bozkır ve doğusunda Karaman ili Kâzımkarabekir ilçesi bulunmaktadır. İlçenin deniz seviyesinden ortalama yüksekliği 1.100 metre olup, yüzölçümü 522,38 km²'dir (Mevlana Kalkınma Ajansı 2014: 2).

Günümüzde Konya-Karaman D715 karayolunun $11 \mathrm{~km}$ batısında yer alan Güneysınır ilçesinin merkezini oluşturan iki yerleşim yeri, Osmanlı Devleti döneminde aynı isimlerle (Güneysınır Resmi Web Sitesi: 2018), Karaman Eyaleti'nin, Konya Sancağı, Belviran Kazası'na (Şafakçı 2016: 60) bağlı köylerdi. Belviran Kazası'nın Larende Sancağı ${ }^{2}$ içerisinde değerlendirildiği XVI. yüzyılın ikinci çeyreğine ait 387 Numaralı Muhâsebe-i Vilâyet-i Karaman ve Rum Defteri'nde, Karasınır ve Elmasun köyleriyle birlikte Belviran'a bağlı 99 köy bulunmaktadır. Ayrıca XVII. ve XIX. yüzyıllar arasındaki hurufat defterlerinde de Karasınır ve Elmasun'un yine Belviran Kazası'na bağlı oldukları görülmektedir (Silay 2015: 25-27).

Cumhuriyet dönemine gelindiğinde, Karasınır ve Elmasun köyleri önce Bozkır ilçesinin Belviran nahiyesinin ${ }^{3}$ köyleri olup, 1955 yılında Bozkır'dan ayrılarak, 1926' da Konya vilayetine bağlı olarak ilçe statüsüne kavuşan Çumra ilçesinin kasabaları haline getirilmişlerdir (GülBayram vd. 2003: 193-194). Cumhuriyet döneminde Elmasun ismi Güneybağ olarak değiştirilmiştir (T.C. Konya Valiliği 1999: 186). 20.05.1990 tarih ve 20523 Sayılı Resmi Gazetede yayınlanan 3644 Sayılı "130 İlçe Kurulması Hakkında Kanun" ile de Güneybağ (Elmasun) ve Karasınır Belediyelerinin tüzel kişiliği kaldırılarak Konya ilinde "Güneysınır" adıyla tek bir ilçe kurulmasına karar verilmiştir (130 İlçe Kurulması Hakkında Kanun: 1990).

\section{1834 ve 1840/41 NÜFUS SAYIMLARINA GÖRE KARASINIR VE ELMASUN KÖYLERI}

Çalışmamızın konusu olan Karasınır ve Elmasun köylerinin bağlı bulunduğu Belviran Kazası'na ait 27 Şubat 1834 (H. 17 Şevval 1249) tarihli nüfus defteri, Türkiye Cumhuriyeti Başbakanlık Devlet Arşivleri Genel Müdürlüğü Osmanlı Arşivleri Daire Başkanlığı'nda BOA, NFS.d kataloğunda 3373 numarada kayıtlı bulunmaktadır. 03. 08. 2011 tarihinde araştırmacıların hizmetine sunulan defter 19x51 ebatlarında olup toplam 67 sayfadan oluşmaktadır. Sayfa usûlü numaralandırma yapılmış olan defter ciltli ve ebrusuzdur. Defterin

\footnotetext{
21530 yılına ait 387 Numaralı Muhâsebe-i Vilâyet-i Karaman ve Rum Defteri'nde, Larende Sancağı'nın kazaya dönüştürülerek Konya Sancağı'na bağlandığı görülmektedir. Dolayısıyla Belviran Kazası da tekrar Konya Sancağı'na bağlanmıştır. bkz. (Şafakçı 2016: 60- 61).

31876 tarihli İdare-i Nevahi Nizamnamesi ile Konya Sancağı nahiyelerinin idarî taksimatında değişiklikler yapılmıştı. Bu dönemde Gaferyad ile birlikte Karaman Kazası' na bağlı bir nahiye olan Belviran, aynı yıl yine nahiye statüsü ile Bozkır Kazası'na bağlanmıştır (T.C. Konya Valiliği İl Kültür Müdürlüğü 1999: 179).
} 
kapak sayfası süslü olup üzerinde "Liva-i Konya Belviran Kazasının nüfus defteridir 1249" yazılı bilgi bulunmaktadır.

Çalışmamızın birinci kaynağı olan 1834 tarihli Belviran Kazası Nüfus Defteri'nin girişinde şu açıklama yapılmıştır: "Bu defa şerefriz-i südûr buyrulan bir kıt'a fermân-ı celilü'l unvan mucibince nüfus-u Belviran kazası kurâlarının bi'l-cümle ehl-i İslâm sigâr ve kibârıve eşkâl ve numra vechi üzere hala eyalet-i Karaman valisi devletlü, übbehetlü el-Hac Ali Paşa hazretlerinin inzimamı rey ve marifeti ve marifet-i şer ile müceddeden tahrir olunan nüfus defteridir ki ber-vech-i âtî zikr ve beyan olunur. Hurrire 17 Şevval 1249." Defter hakkında bu bilginin ardından, ilk olarak "der kaza-i Belviran, der karye-i Gederet" başlığıyla birlikte Gederet köyünün nüfus ve hane bilgileri yazılmıştır. Daha sonra ise kazanın diğer karye ve mahallelerinin nüfus sayımına geçilmiştir.

1834 yılına ait 3373 numaralı Belviran Kazası nüfus kayıtları, hane esasına göre tutulmuştur. İlk olarak hane reisi yazıldıktan sonra sırasıyla o hanede yaşayan erkek nüfus çok nadir istisnalar olmakla birlikte büyükten küçüğe doğru kaydedilmiştir. Kişilerin yaşları isimlerinin altında belirtilmiştir. Hane reisi yazıldıktan sonra erkek çocuğu "oğlu" olarak yazılmış, eğer birden fazla erkek çocuğu var ise "oğulları" şeklinde bilgi verildikten sonra diğer erkek çocuklarının isimleri yazılmıştır. Yerleşim yerlerinde ilk kayıt edilen imamlar ve muhtarlar olmuştur. Bununla birlikte aynı hane içerisindeki kişilerin akrabalık durumlarını belirtmek için ise "karındaşı", "karındaşı oğlu", "emmisi oğlu", "oğlu", "diğer oğlu", "üvey oğlu", "hafidi (torunu), "gulamı" gibi ibareler kullanılmıştır.

İncelemesini yaptığımız 1834 yılı Belviran Kazasına ait nüfus defterinde, Elmasun köyünün nüfus ve hane bilgileri 47. ve 48. sayfalar arasında kayıtlıdır. Karasınır köyünün nüfus ve hane bilgileri ise 49-52. sayfalar arasındadır. Defterin bazı sayfalarında boşluklar bulunmakla birlikte ortalama olarak bakıldığında her sayfada 4-5 satır ve her satırda 6-7 isim bulunmaktadır. Defterde mahalle ve köy isimleri, kişilerin eşkâli, lakabı, mesleği ve adı siyah mürekkepli kalemle yazılırken, hane ve kişilerin sıra numaraları ile dikkat çeken özel durumlar kırmızı mürekkepli kalemle yazılmıştır. 1834 yılına ait nüfus defterinde ölenlerin isminin üzeri çizilerek, yaş ibaresinin bulunduğu alana "fevt", doğanlar için ise "tevellüd" şeklinde not düşülmüştür. Bu notların altına bu kişilerin ölüm ve doğum tarihleri de yazılmıştır. Her mahalle ve köyün bünyesindeki erkek nüfusun yazımı bittikten sonra, sayfa sonlarında yekûn hane ve kişi sayısı verilmiştir.

Araştırmamızın ikinci arşiv kaynağı olan, H. 1256 (1840-41) yılına ait Belviran Kazası Nüfus Defteri ise Türkiye Cumhuriyeti Başbakanlık Devlet Arşivleri Genel Müdürlüğü Osmanlı Arşivleri Daire Başkanlığı'nda BOA, NFS.d kataloğunda 3374 sıralı numarada kayıtlı bulunmaktadır. 03.08.2011 tarihinde araştırmacıların hizmetine sunulan defter, 20x56 ebatlarında olup toplam 224 sayfadan oluşmaktadır. Varak usulü numaralandırma yapılmıştır. Bazı sayfalarda boşluklar olmakla birlikte genellikle her sayfada ortalama 7 satır ve her satırda ortalama 6 isim bulunmaktadır. Ciltli ve ebrusuz olan defterin 1, 29-31, 150-152, 175-178, 196197, 216-217, 223-224 arasında bulunan sayfaları boştur, bu sayfalarda herhangi bir kayıt bulunmamaktadır.

1840-41 yıllarına ait Belviran Kazası nüfus defterinde, bölgedeki nüfusun kayıtları hane esasına göre tutulmuştur. Önce mahalle veya köyün adı yazılmış, daha sonra hane ve sıra numaraları yazıldıktan sonra sırasıyla o hanede yaşayan erkekler büyükten küçüğe doğru kaydedilmiştir. Diğer defterde olduğu gibi yerleşim yerlerinde ilk kayıt edilen imamlar olmuştur. Bununla birlikte aynı hane içerisinde bulunan, hane reisinin oğlu, kardeşi, yeğeni, amcası, damadı, üvey oğlu, gulamı, torunu (hafidi) gibi aile üyesi olan bireylerin de deftere 
yazıldığı görülmektedir.

Belviran Kazası'nın 1840-41 tarihli nüfus defterinin girişinde şu açıklama yapılmıştır: "Tanzimat-ı Hayriye usul-i mehâsin-şümûlüne terfikan tahririne irâde-i seniyye-i şâhâne şeref-ta'alluk buyurulan kazalardan Konya sancağında vaki Belviran kazasının ve karyelerinin nüfus defteridir ki bervech-i âti zikr ve beyan olunur. Sene 1256" Bu açıklamadan sonra "Kaza-i Belviran, tabi' liva-i Konya, hânehâ Karye-i Kurukavak" başlı̆̆ı altında kazanın ilk köyüne ait nüfus ve hane bilgileri yazılmışıtır.

İncelemesini yaptığımız 1840-41 yıllarına ait Belviran Kazasına ait nüfus defterinde, Karasınır köyünün nüfus ve hane bilgileri 198-208 sayfaları arasında kayıtlıdır. Hemen ardından kaydedilen Elmasun köyünün ise nüfus ve hane bilgileri ise 209-215 sayfaları arasındadır. Defterde mahalle ve köy isimleri, kişilerin eşkâli, mesleği, lakabı ve adı siyah mürekkepli kalemle yazılırken; hane ve kişilerin sıra numaraları ile dikkat çeken özel durumlar kırmızı mürekkepli kalemle yazılmıştır. Bu defterde, 1834 yılına ait defterde olduğundan farklı olarak, her mahalle ve köyün bünyesindeki erkek nüfusun yazımı bittikten sonra, sayfa sonlarında toplam nüfus ve hane sayısı hakkında bilgi verilmemiştir. Yine diğer defterden farklı olarak ölenler veya doğanlarla ilgili herhangi bir kayıt bulunmamaktadır.

Araştırmamızın iki ana arşiv kaynağı olan 1834 ve 1840/41 yıllarına ait nüfus defterlerinde, kayıt altına alınan erkek nüfus, hane reisine olan akrabalık derecelerine göre isimleriyle yazılmakla birlikte bu nüfusun eşkâline de yer verilmiştir. Eşkâl bilgilerinde ise genel olarak kişiler, boy, sakal ve bıyığa göre tasnif edilmişlerdir. Kısa, orta, uzun gibi sıfatlarla kişilerin boyları ifade edilmiştir. Ancak XIX. yüzyıla ait nüfus defterlerinin tamamında nüfus standart bir biçimde tasnif edilmemiştir. Belviran Kazası'nın 1834 yılı sayımına ait nüfus defterinde kişilerin boyları ile ilgili herhangi bir kayıt bulunmamaktadır. Sadece sakal ve bıyık özellikleri dikkate alınmıştır. Sakal ve bıyık türleri ise kara, kır, kart, sarı, köse, ter, kumral gibi sıfatlarla betimlenmiştir. 1840-41 yılı sayımında ise hem boy hem sakal özellikleri ile bilgiler yer almaktadır. Bunların dışında iki sayımda da kişilerin yaşları net olarak ifade edilmiştir. Yalnızca 1834 yılına ait defterde askerde olan kişilerin yaş bilgileri bulunmamakla birlikte, 1840/41 yılına ait defterde askerlik görevini ifa eden kişilerin yaşları da yazılmıştır.

Nüfus defterlerinde erkek nüfusun isim, boy, sakal, bıyık gibi eşkal bilgileri dışında kişilerin isimlerinin altında bazı bilgilere rastlanmaktadır. Bu bilgiler kişilerin özel durumlarını tasvir eder niteliktedir. Askerde olan kişilerle ilgili "mansurede", "redif" gibi bilgiler verilirken, bazı kişilerin de "alil (sakat, hastalıkl", "kör", "topal" gibi fizikî durumları belirtilmiştir. Kısaca tanıtımını yaptığımız 1834 ve 1840-41 yıllarına ait bu defterlere bağlı olarak, aşağıda Karasınır ve Elmasun'un demografik yapısı incelenecektir.

\section{A. DEMOGRAFIK YAPI}

\section{Köylerin Nüfusu}

1834 tarihli 3373 numaralı nüfus defterine göre Karasınır köyünde 62 hanede 182 erkek nüfus yaşamaktadır. Aynı defterde Elmasun köyünde ise 42 hanede 106 erkek nüfus bulunmaktadır. Nüfus verilerini kaydeden kişiler tarafından yapılan hesaplamalarda zaman zaman tutarsızlıklar olduğu, kayıtların eksik ya da fazla çıktı̆̆ı, bazı numaraların iki defa yazıldığı gibi nedenlerle hatalı sonuçlara ulaşıldığ1 görülmektedir (Muşmal-Şahinkaya 2015: Elmasun köyünde de sayım memuru erkek nüfusun toplamını 105 olarak vermişse de köydeki 17 numarada kayıtlı bulunan "kara sakallı Mustafa veled-i Gaffar" dan sonra gelen "Hanımoğlu 
Ahmet veled-i Mehmet" isimli kişiyi de tekrar 17. kişi olarak belirtmiştir. Dolayısıyla verdiği yekûn bir eksik çıkmaktadır.

Grafik 1: Karasınır ve Elmasun'da Erkek Nüfus ve Hane Sayıları, 1834.

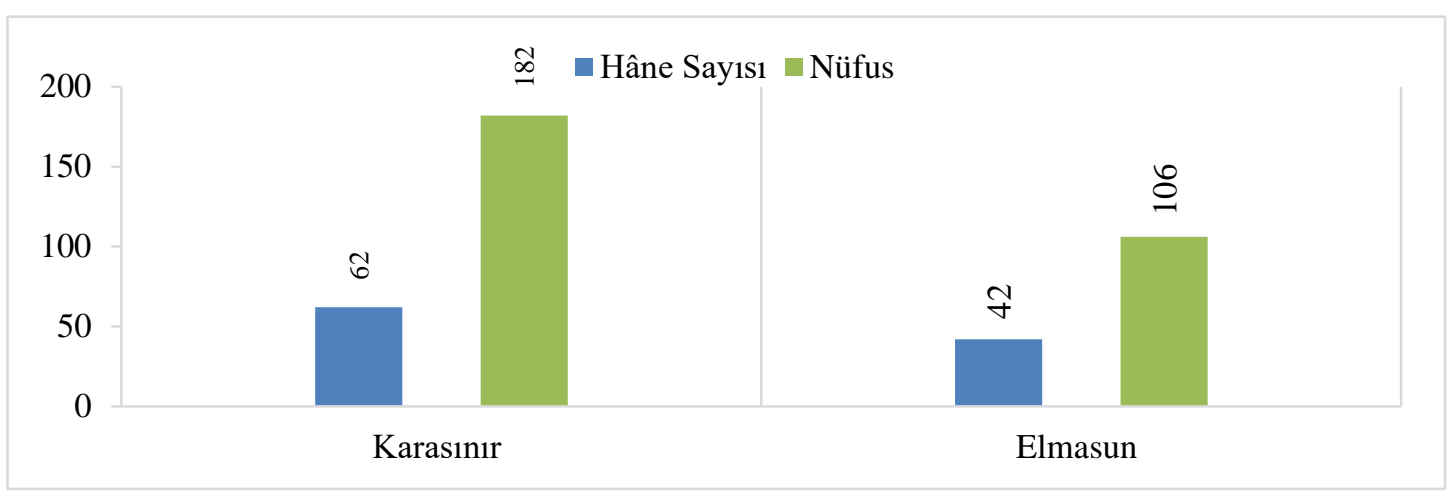

Grafik 1'de görüldüğü üzere, 1834 sayımına göre Karasınır köyü, Elmasun'dan nüfus ve hane sayısı bakımından daha büyüktür. Hane sayısı üzerinden bakıldığında, Karasınır köyünde ortalama olarak her haneye 2,9 erkek düşmektedir. Elmasun köyünde ise ortalama olarak hane başına düşen erkek sayısı yaklaşık olarak 2,5'tir.

İncelediğimiz defterlerde kadın nüfusla ilgili herhangi bir kayıt olmadığı için bölgenin toplam nüfusu ancak tahminî olarak hesaplanabilmektedir. Tahminî nüfus ise genellikle iki metotla hesaplanmaktadır. Bunlardan birincisi, bölgede hane başına düşen kişi sayısının ortalama 5 kişi olduğunu varsayarak, hane sayısının kabaca 5 ile çarpılmasıyla elde edilebilir. İkincisi ise erkek nüfus kadar kadın nüfus bulunduğu düşünülerek, bölgedeki erkek nüfusun 2 ile çarpılmasıyla elde edilebilir. Her iki yöntem de nüfusun kesin olarak tespit edilmesine imkân vermese de en yakın tahmine bu metotlarla ulaşmak mümkündür (Muşmal-Şahinkaya 2015: 486). Çalışmamızda erkek nüfus kadar kadın nüfus bulunduğu kabul edilerek yapılan ikinci metot esas alınmıştır. Dolayısıyla bu yöntemi kullandığımızda Karasınır köyünün 1834 tarihindeki toplam nüfusu yaklaşı olarak 364, Elmasun köyünün ise 212 olduğunu anlaşılmıştır. Buna göre iki köyün 1834 yılındaki toplam nüfusunun yaklaşık 576 kişi olduğunu söylenebilir. Grafik 2'de görüldügüu üzere toplam nüfusunun \%63'ünü Karasınır oluştururken \%37'sini ise Elmasun köyü oluşturmaktadır. 
Grafik 2: Karasınır ve Elmasun'un Tahminî Nüfusu ve Oranları, 1834.

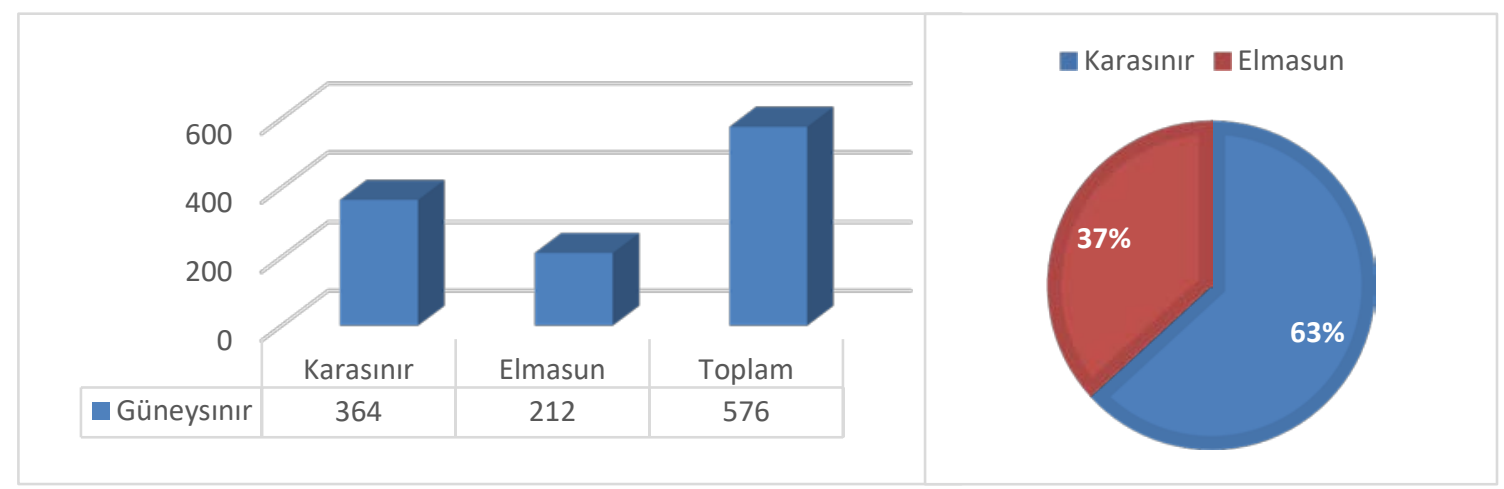

1840-41 tarihli 3374 numaralı nüfus defterine göre Karasınır'da 55 hanede 199 erkek nüfus yaşamaktadır. Aynı defterde Elmasun'da ise 47 hanede 132 erkek nüfus bulunmaktadır. Buna göre 1840-41 sayımında da Karasınır, Elmasun'dan nüfus ve hane sayısı bakımından fazladır. 1840-41 tarihli sayımda, 1834 tarihli sayıma göre Karasınır nüfusunun 17 kişi arttığ1 görülmektedir. Hane sayısı ise 55'e düşmüştür. 1834 yılındaki ilk sayımda ayrı hanelerde bulunan bazı bireylerin ikinci sayımla beraber aynı hanede yaşadıkları görülmüştür. Nüfus artarken hane sayısındaki düşüşün sebebinin bu olduğu söylenebilir. Elmasun'da ise hem nüfus hem hane sayısı artış göstermiştir. Hane sayısı 42 iken 47'ye yükselmiş olup, erkek nüfus ise 106'dan 132'ye yükselmiştir. Buna göre Elmasun'un Karasınır'a göre nüfus artış hızının daha yüksek olduğu söylenebilir. Karasınır'da daha önceki sayımda hane başına düşen erkek nüfus yaklaşık olarak 2,9 iken 1840-41 tarihli sayımda bu oran yaklaşık 3,6'ya yükselmiştir. Elmasun'da ise önceki sayımda 2,5 olan oran yaklaşık olarak 2,8'e yükselmiştir.

Grafik 3: Karasınır ve Elmasun'da Erkek Nüfus ve Hane Sayısı, 1840-41.

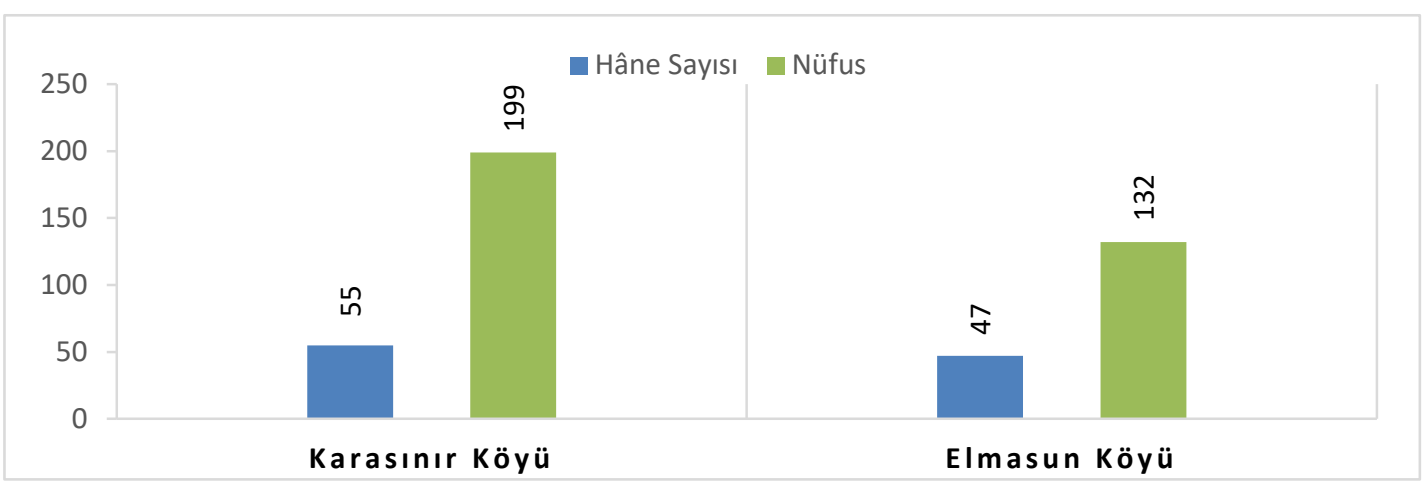

Erkek nüfus kadar kadın nüfusun da olduğu düşünülerek erkek nüfus 2 ile çarpıldığında Karasınır'da tahminî toplam nüfus 398, Elmasun'da ise 264 olarak ortaya çıkmaktadır. Dolayısıyla iki köyün tahminî toplam nüfusu bir önceki sayıma göre 86 kişi artarak 662'ye ulaşmıştır. Bir önceki sayımda toplam nüfusun \%63'ünü Karasınır, \%37'sini Elmasun oluştururken, Grafik 4'te görüldüğü üzere, bu sayımda \%60'ını Karasınır \%40'ını Elmasun oluşturmaktadır. Buna göre Elmasun'un toplam nüfus içindeki oranının artış gösterdiğini söyleyebiliriz. 


\section{Grafik 4: Karasınır ve Elmasun'un Toplam Tahminî Nüfusu, 1840-41.}

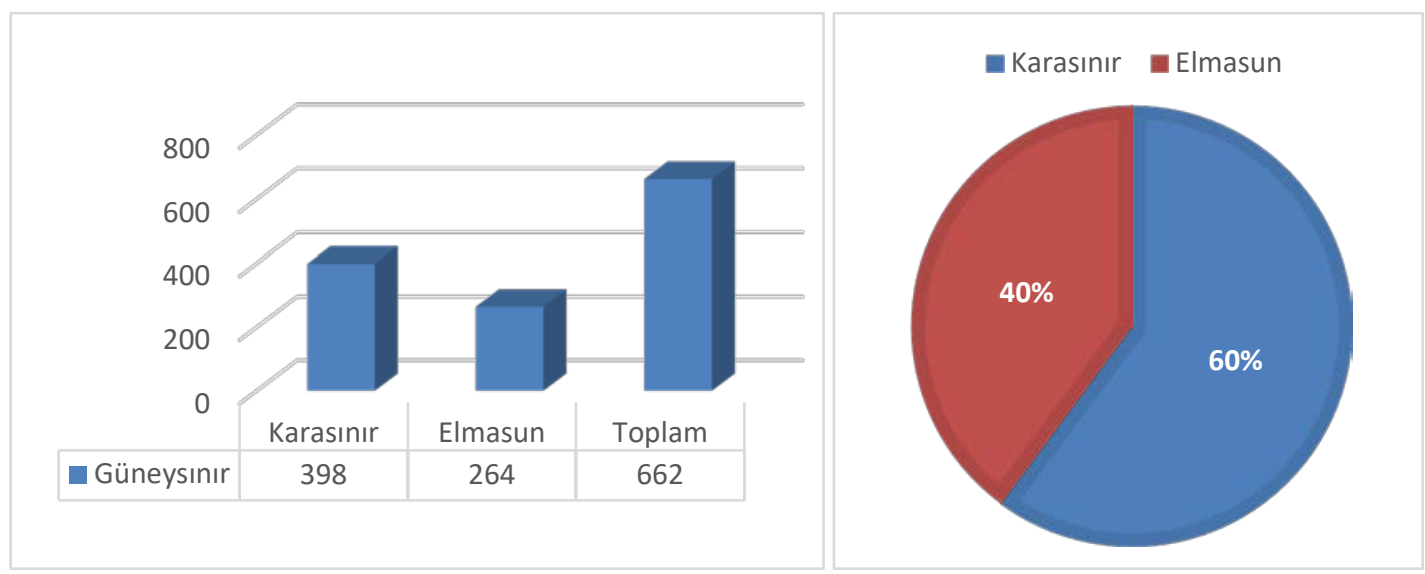

\section{Nüfus Hareketleri}

Göç kısaca insanların bir yerleşim yerinden başka bir yerleşim yerine gitmelerine denmektedir. Göç hareketleri neden ve sonuçlarıyla birlikte bir süreç olarak kabul edilebilir. Bu nedenle de göçler üzerine yapılan araştırmalarda göç tanımı için iç-dış, ekonomik-siyasî, sürekli-geçici, gönüllü-zorunlu göçler gibi farklı gruplandırmalar yapılmıştır (Muşmal 2006: 269-270). Bazı nüfus defterlerinde yerleşim yerlerindeki göçlerle ilgili bilgilere de rastlanmaktadır.

Göçlerle ilgili olarak Karasınır ve Elmasun köylerinin 1834 ve 1840/41 yılına ait nüfus defterleri incelendiğinde sadece 1834 yılına ait Karasınır köyünde bir tane kayda rastlanmaktadır. Buna göre Karasınır köyünde 28 yaşındaki Ahmet veled-i Hasan isimli bir kişiye "diyâr-ı âharda" şeklinde not düşülmüştür. Diyâr-1 âharda, başka bir memlekette anlamına gelmektedir. Nüfus defterlerinde nerede oldukları tam olarak bilinmeyenler için "diyâr-ı âhar" kaydıyla durumları tasvir edilmiştir (Gül 2015: 162). Karasınır ve Elmasun bölgesinde, incelenen dönemde dışarıya çok fazla göç yaşanmamasının sebebi, bölgedeki arazi ve yaşam koşulları ile sağlık koşullarının sair bölgelere göre daha iyi olmasından kaynaklanmış olabilir. ${ }^{4}$

\section{Yaş Dağılımı}

Nüfus defterlerinin bize sağladığı önemli verilerden birisi de nüfusun yaşı ile ilgili bilgilerdir. Çünkü sayımlarda bir bölgedeki bütün erkek nüfus kayıt altına alınmıştır. Yaş bilgilerinin sayesinde nüfus defterlerinin hazırlandığı tarihte, bölgedeki kişilerin ortalama yaşı ve yaşam süresi hakkında bazı tahminler yürütülebilmektedir.

Daha önce ifade edildiği gibi 1834 yılı sayımlarına göre Karasınır köyünde 182 erkek nüfus bulunmaktaydı. Bu tarihte Karasınır köyünden 7 kişi askerde olduğu için yaş bilgisi bulunmamaktadır. Ayrıca asker olanların dışında katip hatasından kaynaklandığını düşündüğümüz 1 kişinin de yaş bilgisi verilmemiştir. Dolayısıyla söz konusu sayımda 182 kişiden toplam 8 kişinin yaş bilgisinden yoksun bulunmaktayız. Yaş bilgisine sahip olduğumuz bütün erkek nüfus göz önüne alındığında Karasınır köyünün ortalama yaşı 23,2 olarak ortaya çıkmaktadır. 1834 sayımına göre Elmasun köyünde ise 106 kişiden 6 kişinin askerde olması sebebiyle yaş bilgisi bulunmamaktadır. Buna göre Elmasun köyünün 1834 sayımına göre yaş

4 Bu konuda Beyşehir örneği için bkz. (Muşmal 2006: 269-284) 
ortalaması $26,09^{\prime}$ dur. İki köyün toplam nüfusunun yaş ortalaması ise 24,3 olarak ortaya çıkmaktadır. Bu sonuçlara göre incelenen köylerin oldukça genç bir nüfus yapısına sahip olduğunu söyleyebiliriz.

1840-41 yılı sayımlarında ise Karasınır ve Elmasun köylerinde yaşayanların tamamının yaş bilgisi kaydedilmiştir. Buna göre 1840-41 sayımında Karasınır'da erkek nüfus 17 kişi artarken yaş ortalaması 23,2'den 23,8'e yükselmiştir. Elmasun'da ise erkek nüfus 26 kişi artarken, yaş ortalaması ise $21,7^{\prime}$ ye düşmüştür. İki köyün toplam erkek nüfusunun yaş ortalaması ise $24,3^{\prime}$ ten 23'e düşmüştür.

Elimizdeki verilere göre iki yerleşimde yaşayan erkeklerin hangi yaş aralıklarında yoğunlaştıkları ve hangi yaş grubunun hâkim unsur olduğunu da tespit etmek mümkün olmaktadır. 1834 sayımına göre Karasınır'da, çocuk olarak kabul edilebilecek olan 0-10 yaş grubu 64 kişi, 11-21 yaş grubunda 23 kişi, 22-30 yaş grubunda 28 kişi, 31-40 yaş grubunda 23 kişi, 41-50 yaş grubunda 20 kişi, 51-60 yaş grubunda 14 kişi, 61-70 yaş grubunda ise 2 kayıtlı kişi bulunmaktadır. Buna göre köyde yaşayanların en büyük çoğunluğunu \%37 ile 0-10 yaş grubu oluşturmaktadır. ${ }^{5}$ Köyde kaydedilen en küçük yaş 1 iken, en yaşlı kişi ise 70 yaşındadır. ${ }^{6}$

\section{Grafik 5: Karasınır Köyü Yaş Aralığı ve Yüzdeleri, 1834.}

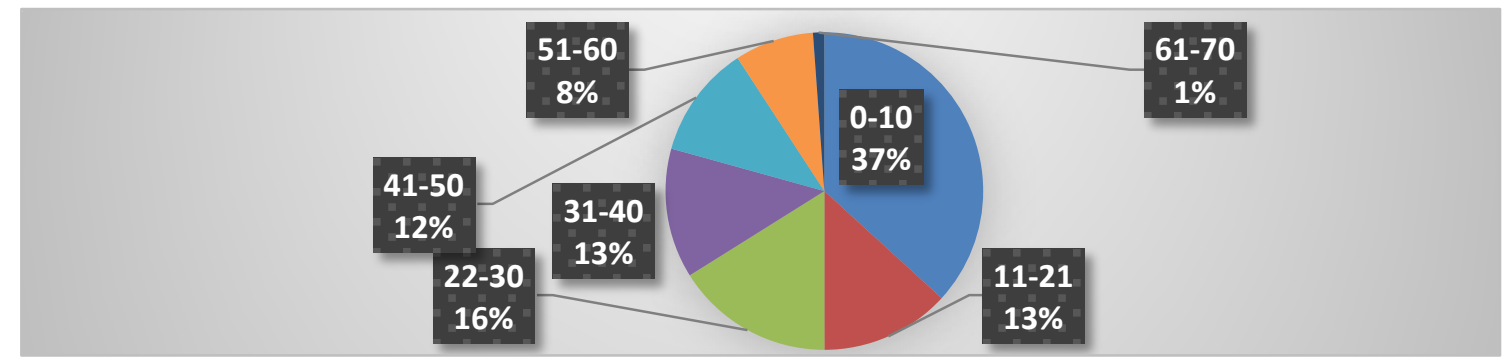

1834 sayımına göre Elmasun'da ise 0-10 yaş grubu 34 kişi, 11-21 yaş grubunda 14 kişi, 22-30 yaş grubunda 13 kişi, 31-40 yaş grubunda 14 kişi, 41-50 yaş grubunda 9 kişi, 51-60 yaş grubunda 11 kişi, 61-70 yaş grubunda ise 5 kayıtlı kişi bulunmaktadır. Buna göre karyenin en büyük çoğunluğunu \%34 ile Karasınır'da olduğu gibi 0-10 yaş grubu oluşturmaktadır.7 Köyde kaydedilen en küçük yaş 1 iken, en yaşlı kişi ise 70 yaşındadır. ${ }^{8}$

1834 yılında Karasınır köyündeki erkek nüfusun yaş aralıkları ve yüzdeleri için bkz. Grafik 5.

Hane 4, numara 9'da hane reisi Ak Sakallı Çul Evli Ali veled-i Ali isimli kişi 70 yaşında olarak kaydedilmiştir.

1834 yılında Elmasun köyündeki erkek nüfusun yaş aralıkları ve yüzdeleri için bkz. Grafik 6.

1834 yılında Elmasun'da 70 yaşında kaydedilmiş olan 3 kişi bulunmaktadır. Bunlar sırasıyla, hane 18, numara 38'de bulunan Ak Sakallı Dineklioğlu Mustafa veled-i Mustafa, hane 30 numara 75'de kayıtlı bulunan Ak Sakallı İbiş veled-i Hasan, ve hane 38 numara 96' da kayıtlı Ak Sakallı Seyid veled-i Ali isimli kişilerdir. 
Grafik 6: Elmasun Köyü Yaş Aralığı ve Yüzdeleri, 1834.

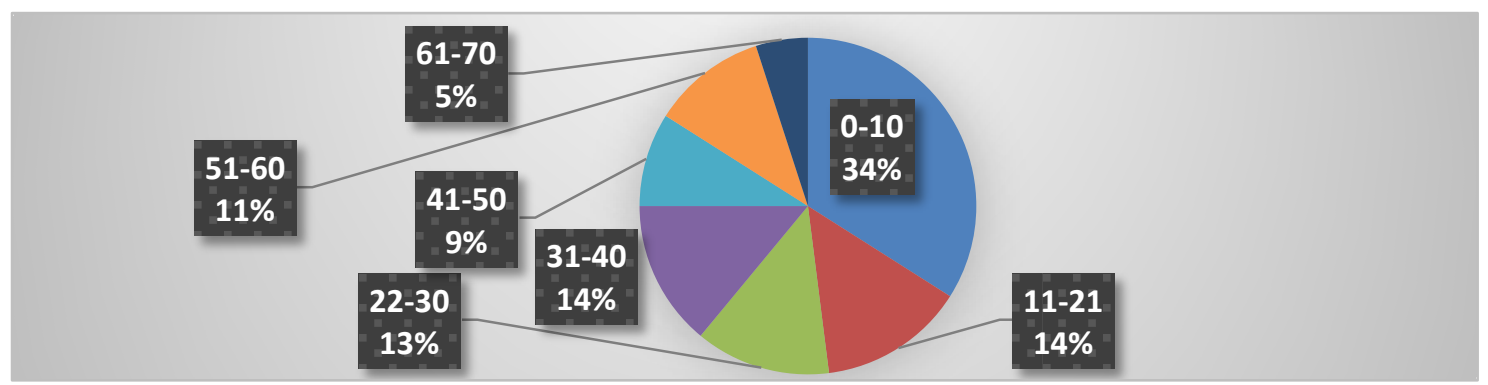

Her iki köyün toplam erkek nüfusuna baktı̆̆ımızda ise 0-10 yaş grubu 98 kişi, 11-21 yaş grubunda 37 kişi, 22-30 yaş grubunda 41 kişi, 31-40 yaş grubunda 37 kişi, 41-50 yaş grubunda 29 kişi, 51-60 yaş grubunda 25 kişi, 61-70 yaş grubunda ise 7 kayıtlı kişi bulunmaktadır. Buna göre iki köyün toplam nüfusunun en büyük bölümünü \%36 ile 0-10 yaş grubu oluşturmaktadır. En küçük bölümünü ise \%3 ile 61-70 yaş grubu oluşturmaktadır. ${ }^{9}$

Günümüz değerleri açısından düşünüldüğünde yaşlı olarak nitelendirilebilecek insanların 60-65 yaş ve üzerindeki insanlar olduğu söylenebilir. Ancak XIX. yüzyıl şartlarında ortalama yaşam süresinin günümüzden oldukça düşük olduğu hesaba katılırsa 50 yaş ve üzerinde olan insanların yaşlı olarak değerlendirilmesi daha uygun olur. Bunun için 0-10 yaş grubu çocuk, 1130 yaş grubu genç, 30-50 yaş grubu orta yaşlı, 50 ve üzerindekiler ise yaşlı olarak kabul edilmiştir (Muşmal-Şahinkaya 2015: 489-490). Bu parametrelere göre yapılan değerlendirmelerde iki köydeki erkek nüfusun 50 yaşın üzerinde olanlarının sayısı 32 iken, onların ortalama yaşları 60 olarak ortaya çıkmaktadır. Buna göre, çocukların (0-10) oranı $\% 35,77$, gençlerin (11-30) oranı \%28,47, orta yaşlıların (31-50) oranı \%24,09, yaşlıların (50-100) oranı \%11,68 olarak ortaya çıkmaktadır. Buradan hareketle ortalama yaşın da 24,3 olduğu düşünülerek Karasınır ve Elmasun'nun önemli bir genç nüfusa sahip olduğu, 50 yaşın üzerinde olanların oranının oldukça düşük olması sebebiyle de ortalama ömrün günümüz açısından değerlendirildiğinde oldukça düşük seviyede olduğunu söyleyebiliriz.

Grafik 7: Karasınır ve Elmasun Köylerinin Yaş Aralığı ve Yüzdeleri, 1834.

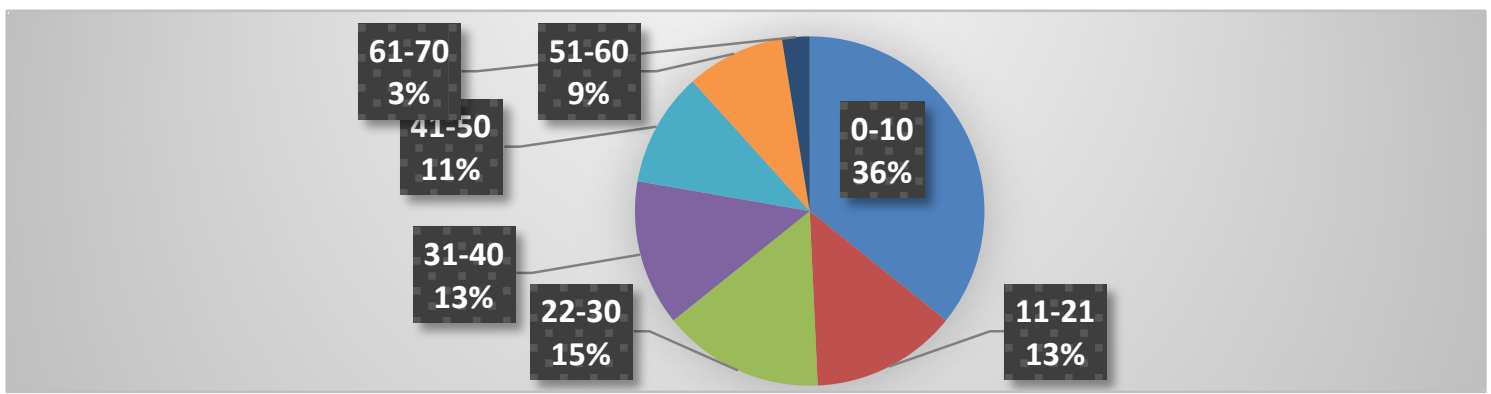

1840-41 sayımına göre ise Karasınır'da 0-10 yaş grubu 84 kişi, 11-21 yaş grubunda 17 kişi, 22-30 yaş grubunda 32 kişi, 31-40 yaş grubunda 23 kişi, 41-50 yaş grubunda 20 kişi, 51-60 yaş grubunda 8 kişi, 61-70 yaş grubunda ise 11 kayıtlı kişi, 71-80 yaş grubunda 2 kişi, $81-90$ yaş grubunda ise yine 2 kişi bulunmaktadır. Buna göre köyün en büyük çoğunluğunu önceki

${ }^{9} 1834$ yılında Elmasun ve Karasınır köyündeki toplam erkek nüfusun yaş aralıkları ve yüzdeleri için bkz. Grafik 7. 
sayımda olduğu gibi \%42 ile 0-10 yaş grubu oluşturmaktadır. ${ }^{10}$ Karyede kaydedilen en küçük yaş 1 iken, en yaşlı kişisi ise 90 yaşındadır. ${ }^{11}$

Grafik 8: Karasınır Köyünün Yaş Aralığı ve Yüzdeleri, 1840/41.

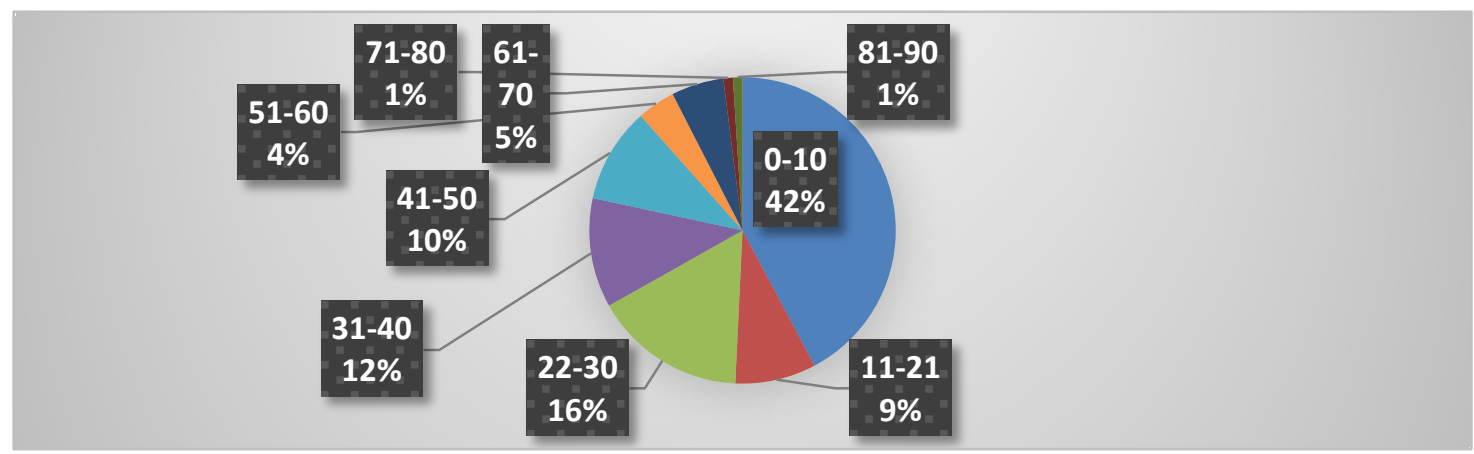

1840-41 sayımına göre ise Elmasun'da 0-10 yaş grubu 59 kişi, 11-21 yaş grubunda 18 kişi, 22-30 yaş grubunda 13 kişi, 31-40 yaş grubunda 18 kişi, 41-50 yaş grubunda 11 kişi, 51-60 yaş grubunda 6 kişi, 61-70 yaş grubunda ise 7 kayıtlı kişi bulunmaktadır. Buna göre köyün en büyük çoğunluğunu önceki sayımda olduğu gibi \%45 ile 0-10 yaş grubu oluşturmaktadır.

\section{Grafik 9: Elmasun Köyünün Yaș Aralığı ve Yüzdeleri, 1840/41.}

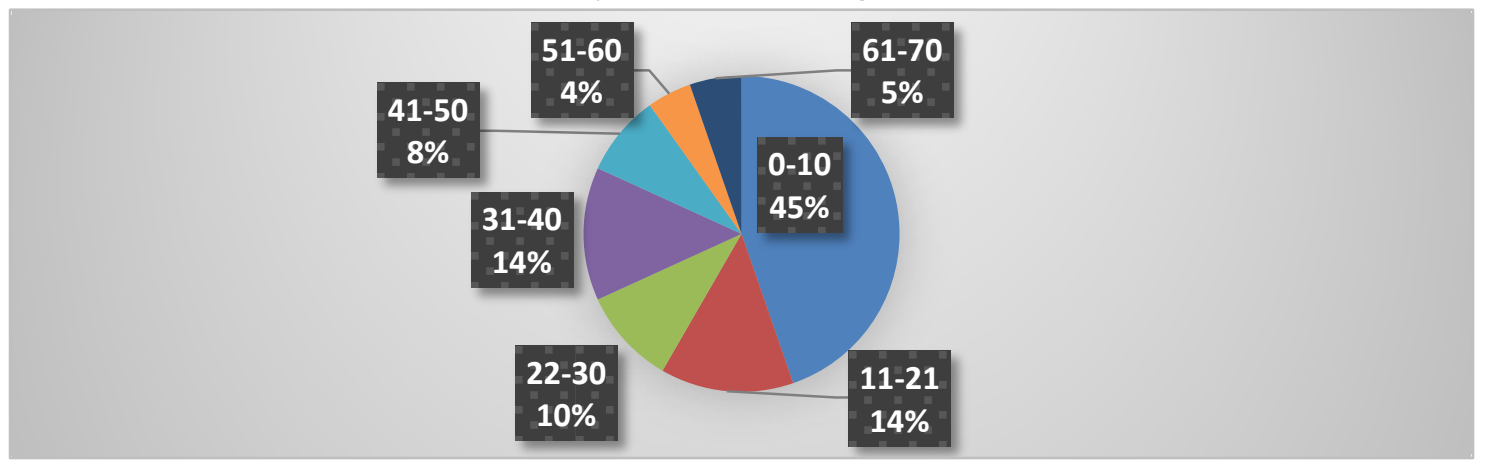

İki köyün toplam erkek nüfusuna baktığımızda ise 0-10 yaş grubu 143 kişi, 11-21 yaş grubunda 35 kişi, 22-30 yaş grubunda 45 kişi, 31-40 yaş grubunda 41 kişi, 41-50 yaş grubunda 31 kişi, 51-60 yaş grubunda 14 kişi, 61-70 yaş grubunda 18 kişi, 71-80 grubunda 2 kişi ve 81-90 yaş grubunda ise yine 2 kayıtlı kişi bulunmaktadır. Buna göre iki köyün toplam nüfusunun en büyük bölümünü \%43 ile 0-10 yaş grubu oluşturmaktadır. ${ }^{12}$ Bu verilere göre, çocukların (0-10) oranı $\% 43,20$, gençlerin (11-30) oranı $\% 24,17$, orta yaşlıların (31-50) oranı $\% 21,75$, yaşlıların (50$100)$ oranı $\% 10,88$ olarak ortaya çıkmaktadır.

1840/41 yılında Karasınır köyündeki erkek nüfusun yaş aralıkları ve yüzdeleri için bkz. Grafik 8.

11 1840-41 yılındaki sayımda Karasınır'da 90 yaşında iki kişinin yaşadığı görülmektedir. Bunlardan birincisi hane 28, numara 115'de kayıtlı olan Orta boylu Ak Sakall Abdülkerim veled-i Hacı Hamza, ikincisi de hane 73 numara 193'te Orta boylu Ak Sakall Mustafa veled-i Türkmen isimli kişidir.

12 1840/41 yılında Karasınır ve Elmasun köylerindeki toplam erkek nüfusun yaş aralıkları ve yüzdeleri için bkz. Grafik 8. 
Grafik 10: Karasınır ve Elmasun Karyelerinin Yaş Aralığı ve Yüzdeleri, 1840/41.

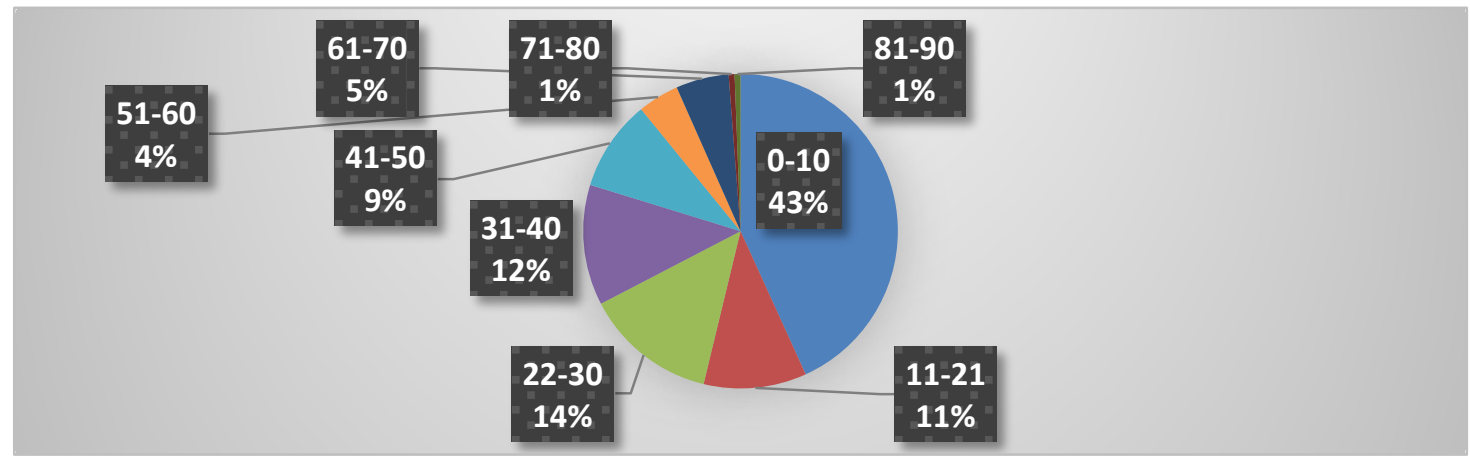

Yukarıdaki grafiklerde görülebileceği üzere iki sayımda da yaş grupları arasında en büyük oranı 0-10 yaş grubu oluşturmaktadır. Ayrıca incelenen dönemde köylerdeki 50 yaş üzerindeki nüfusun oranlarının ise oldukça düşük olması sebebiyle de ortalama ömrün günümüze göre daha düşük olduğu açıtır. Bu verilere göre incelenen yerleşimlerde doğum ve ölüm oranlarının yüksek olduğu söylenebilir.

\section{Aile Yapısı ve Çocuk Sayısı}

Nüfus defterlerinde her aile bir hane olarak kayda geçirilmiştir. Hanedeki bütün erkekler de hane reisinin çatısı altında kaydedilmiştir. Bu nedenle geniş aile içerisinde bulunan evli veya bekâr erkekler de aynı hane içerisinde gösterilmiştir. Böylece defterlerdeki verilerden hareketle incelenen yerleşimlerde yaşayan ailelerin çekirdek veya geniş aile olup olmadığı gibi özellikler ve bunların yerleşim birimlerindeki oranlarına ulaşılabilmektedir (Muşmal-Şahinkaya 2015: 490).

1834 tarihli nüfus defterinde Karasınır ve Elmasun köylerinde 105 hane reisi çatısı altında 121 kişi oğlu, 26 kişi karındaşı, 7 kişi karındaşı oğlu, 19 kişi torunu, 4 kişi üvey oğlu, 2 kişi yeğeninin oğlu, 2 kişi damadı, 1 kişi babalığı 1 kişi de gulamı olarak kaydedilmiştir. ${ }^{13}$

Defterlerde hane reisinin oğlu olarak kaydedilen erkek çocuklarının evli olup olmadıkları kesin olarak bilinememektedir. Ancak hanede torunu olarak birisi kaydedilmiş ise hane reisinin oğlu evli olduğu kesinleşmektedir. Bir hanede yaşı belirtilmesine rağmen hane reisinin oğlu olarak kaydedilenleri çekirdek ailenin üyesi olarak düşünmek mümkündür. Ancak hane reisinin kardeşi, kardeşinin oğlu, torunu, torunun oğlu, emmisi, emmisi oğlu, damadı, damadı oğlu, yeğeni, üvey babası, üvey kardeşi ve üvey oğlu olarak kaydedilenleri geniş ailenin üyeleri olarak değerlendirmek daha doğrudur (Muşmal-Şahinkaya 2015: 490).

131834 yılında, Karasınır ve Elmasun köylerindeki hanelerde bulunan nüfusun hane içindeki dağılım oranı için bkz. Grafik 11. 
Grafik 11: Karasınır ve Elmasun'da Hane Reisi Hariç Nüfusun Hane İçindeki Dağılım Oranı, 1834.

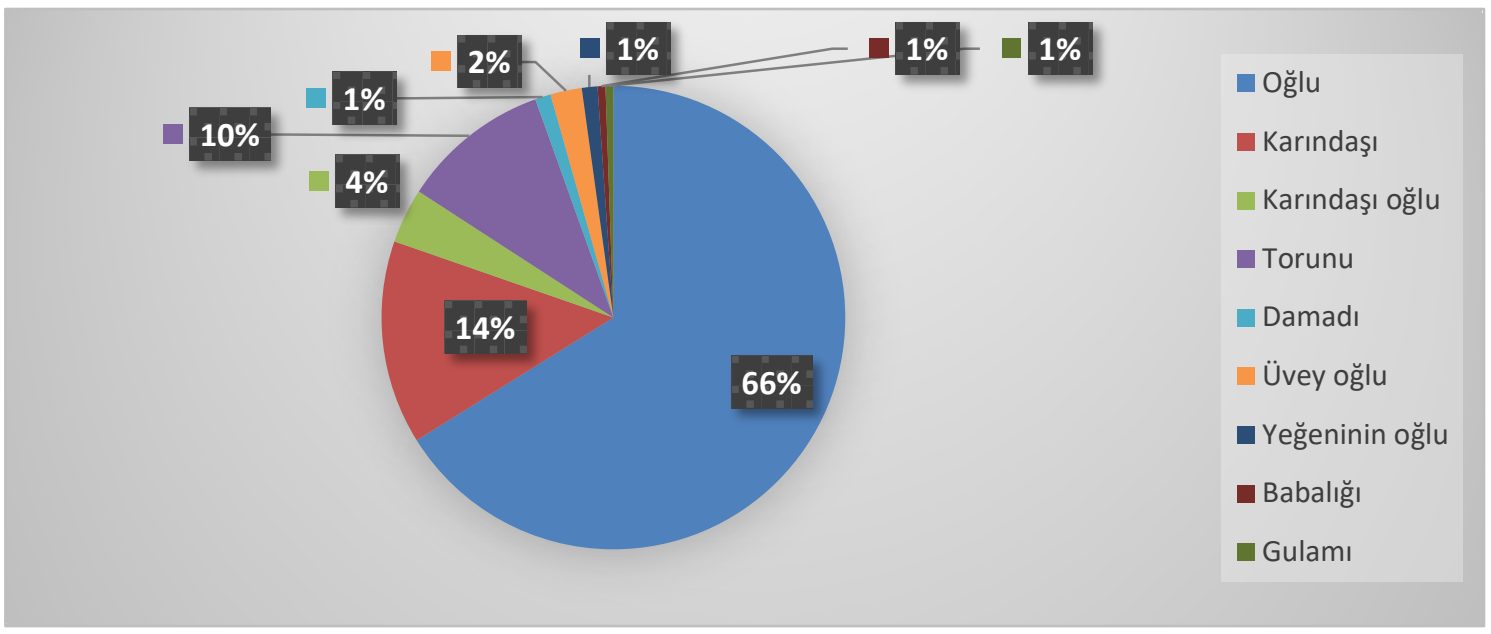

1834 sayımında Karasınır ve Elmasun genelinde hane reisi ve oğlu dışındaki aile üyeleri olan erkeklerin geniş aileyi oluşturan bireyler olduğu düşünülerek bunların bütün hane üyeleri içerisindeki yerine bakıldığında hane reisi ve oğlu dışındaki aile erkeklerinin \%35 oranında olduğu görülmektedir. Bu yönüyle Elmasun ve Karasınır'da geniş aile oranının en azından \%35 civarında olduğu söylenebilir. İki köyde toplam 36 hane geniş aile özelliği göstermesine karşın 68 hane de çekirdek aile özelliği göstermektedir. ${ }^{14}$

Her iki köy ayrı ayrı değerlendirildiğinde ise Karasınır köyündeki geniş aile oranının Elmasun'a göre bir hayli yüksek olduğu söylenebilir. Karasınır köyünde geniş aile oranı yaklaşık \%42 iken, Elmasun karyesinde bu oran \%24 civarlarındadır. Bu sonuçlar, XIX. yüzyılın ikinci çeyreğinde Karasınır ve Elmasun köylerinde çekirdek aile tipinin daha baskın olduğunu göstermektedir.

Grafik 12: Karasınır ve Elmasun'un Aile Yapısı, 1834.

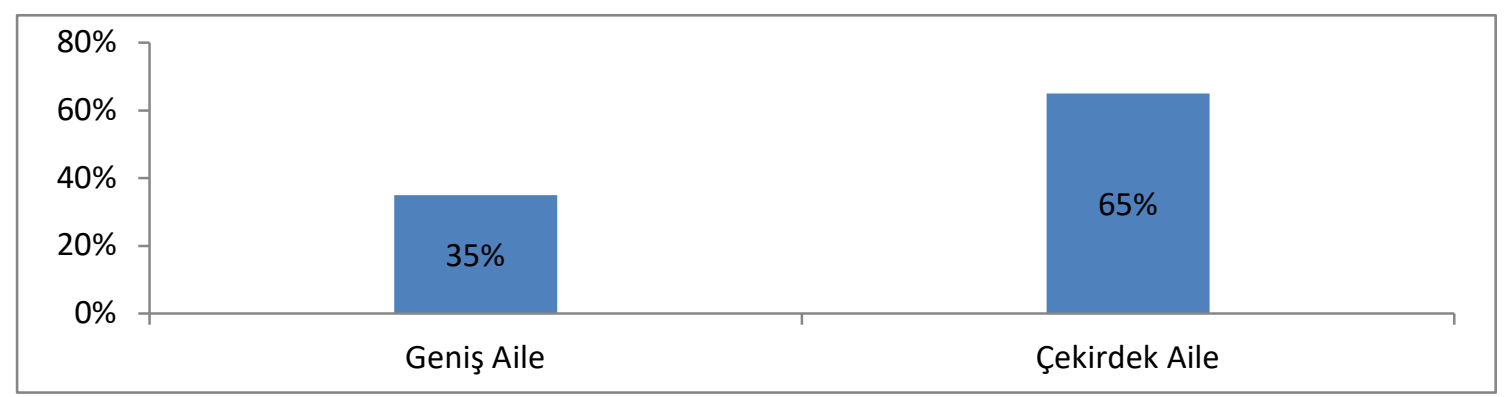

1840/41 yılına ait Belviran Kazası nüfus defterinde ise Karasınır ve Elmasun köylerinde 102 hane reisi çatısı altında 136 kişi oğlu, 33 kişi karındaşı, 27 kişi karındaşı oğlu, 16 kişi torunu (hafidi), 3 kişi üvey oğlu, 2 kişi emmisi oğlu, 2 kişi karındaşının hafidi, 2 kişi yeğeninin oğlu, 4 kişi damadı, 1 kişi gulamı, 1 kişi emmisi, 1 kişi üvey babası, 1 kişi üvey karındaşı olarak kaydedilmiştir.

141834 yılında Karasınır ve Elmasun'un aile yapısı için bkz. Grafik 12. 
Grafik 13: Hane Reisi Hariç Nüfusun Hane İçindeki Dağılım Oranı, 1840/41.

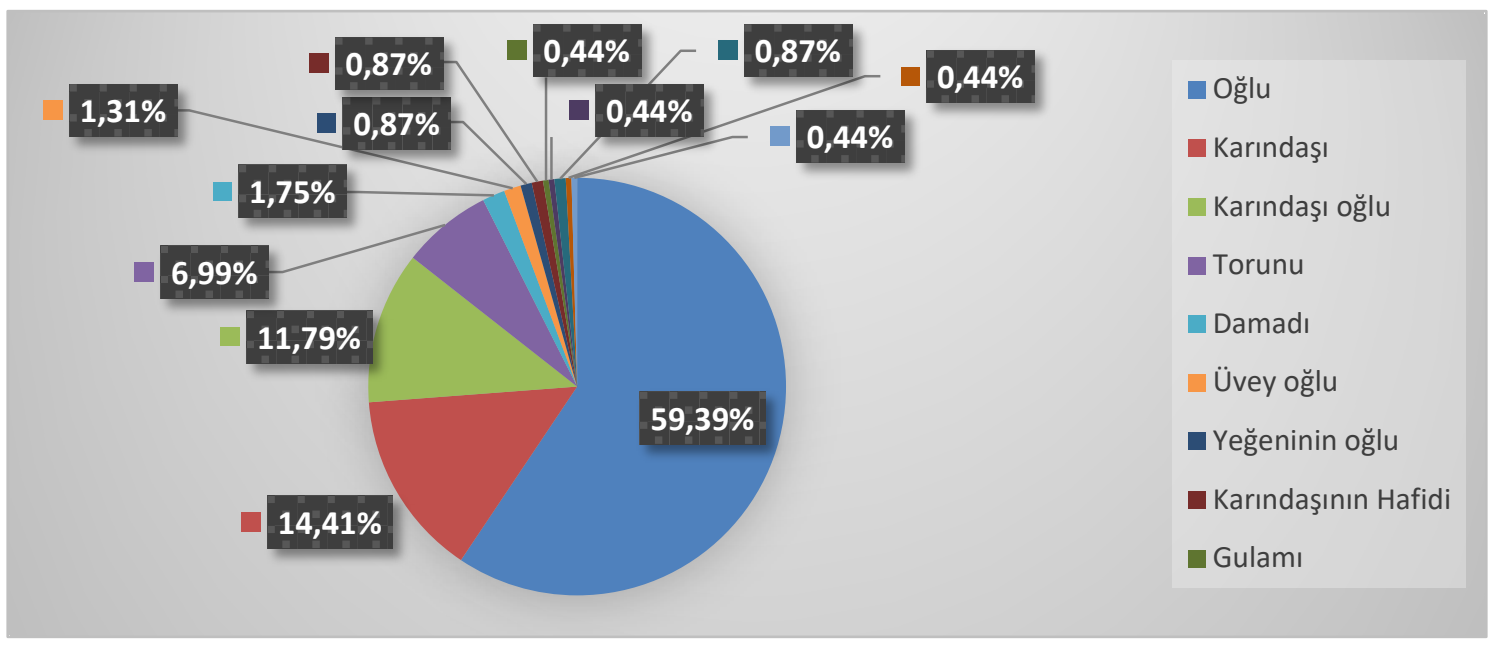

1840/41 yılı sayımında ise Karasınır ve Elmasun genelinde hane reisi ve oğlu dışındaki aile erkeklerinin \%39 oranında olduğu görülmektedir. Bu yönüyle Elmasun ve Karasınır'da geniş aile oranının 1840/41 yılında en azından \%39 civarında olduğu söylenebilir. İki köydeki toplam 102 haneden 40 tanesi geniş aile özelliğini gösterirken, 62 tanesi ise çekirdek aile tipine uygun görünmektedir. Bir önceki sayıma göre geniş aile oranı \%4 artmıştır. Köyler ayrı ayrı değerlendirildiğinde ise Karasınır' da geniş aile oranı yaklaşık \%40 iken, Elmasun köyünde bu oran \%38 civarlarındadır. Elmasun'da geniş aile oranı bir önceki sayıma göre yükselmiştir.

Grafik 14: Karasınır ve Elmasun'un Aile Yapısı, 1840/41.

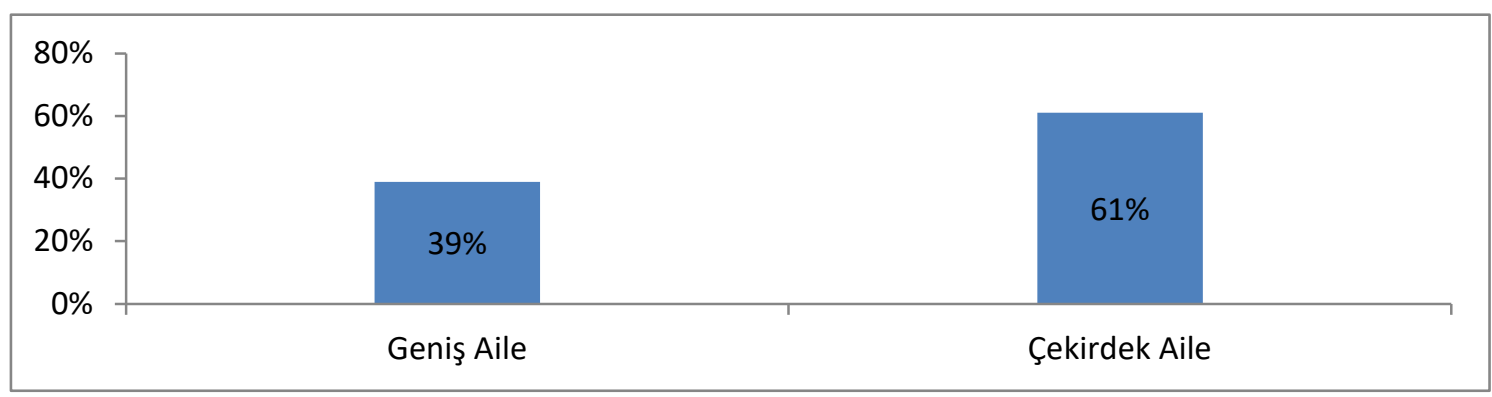

Defterler genel itibariyle değerlendirildiğinde, bazen hane reisinin oğlu olarak kaydedilmiş iki kardeş arasında baba isminde farklılıklar olduğu görülmektedir. Bu durumda, hane reisinin eşinin ikinci evlilik yaptığı ve önceki evliliğindeki çocuğuyla birlikte bu eve gelmiş olabileceği düşünülmektedir. Örneğin, 1840/41 yılında Karasınır'da hane 9 sayı 35'te Mehmet veled-i Abdullah, hane reisinin oğlu olarak kaydedilmesine rağmen, hane reisinin ismi Halil olduğu için baba ismi uyuşmamaktadır. Yine hane 34 sayı 136'da Ahmet veled-i Ahmet isimli kişide aynı durum karşımıza çıkmaktadır. Bir başka belirtilmesi gereken durum ise 1840/41'de Elmasun'daki sayımda hane 30 sayı 86 'da hane reisinin karındaşı olarak kaydedilen kişinin katip hatası sebebiyle isminin yazılmadığı görülmektedir.

İncelediğimiz defterlerde 5, 7, 8 gibi küçük yaştaki kişilerin hane reisi olarak kaydedildiği görülmektedir. Örneğin, 1834 sayımında Karasınır'da hane 37'de Ahmet veled-i Ahmet isimli kişi 8 yaşındadır. Yine hane 56'da Eniklioğlu Kadir veled-i Halil hane reisi olarak kaydedilmesine 
rağmen 5 yaşındadır. Aynı sayımda Elmasun'da hane 11'de Mustafa veled-i Abdüllatif 8 yaşında, hane 32'de Mehmet veled-i Imam Mehmet 5 yaşında, hane 42'de Mehmet veled-i Hüseyin yine 5 yaşındadır. Bu durum bize aile reisinin ölümü ya da herhangi bir sebep yüzünden evinden ayrılması nedeniyle hanede bulunan en büyük erkek kim ise onun hane reisi olarak kaydedildiğini düşündürmektedir.

1834 yılına ait defterde, incelediğimiz köylerde toplam 134 kişi oğlu olarak kaydedilmiştir. 1840/41 yıllarındaki defterde ise toplam 170 kişi oğlu olarak kaydedilmiştir. Bunların bir kısmının ailenin evli çocuklarının olduğu görülmektedir. Söz konusu sayı, toplam hane sayısına bölündüğünde bir hane içerisindeki yaklaşık erkek çocuk sayısına ulaşmak mümkündür. Buna göre 1834 yılında Karasınır ve Elmasun'da hane başına yaklaşık 1,28 erkek çocuk düşmektedir. 1840/41 yılında ise bu oran 1,66'ya yükselmiştir. Bu durum da Osmanlı ailesinin hâkim tipi olan çekirdek aile yapısına uygun görünmektedir.

\section{B. ŞAHISLARIN TIPOLOJİİ, İSIM VE LAKAPLARI}

\section{Tipoloji}

Nüfus sayımı yapılan bölgelerde yer alan şahısların fizikî özellikleriyle ilgili bilgilerin de defterlere kaydedildiği görülmektedir. Bu fizikî tanımlamalarda kişiler belli özelliklerine göre tasvir edilmişlerdir. Genel olarak boy, sakal, bıyık gibi unsurlar kişileri tanımlamada esas alınmıştır. Ancak genellikle erişkin bireylerde bu tür sınıflamalar yapılmıştır. Çocuk yaştakilerle ilgili söz konusu tasvirlere pek rastlanmamaktadır. Buna göre bir kişinin boyunun kısa, orta veya uzun olarak hangisine uyduğu ifade edildikten sonra sakalının ak, kır, kırca, kara, kumral, sarı, köse ya da şâb emred tanımlamalarından hangisine uygun olduğu belirtilmektedir. Kişinin sakalı yok ise bıyı̆̆ı ter, kart gibi sıfatlarla ifade edilmektedir (MuşmalŞahinkaya 2015: 492-493).

İncelediğimiz 1834 ve 1840/41 yıllarına ait defterlerden ise 1834 yılına ait olan Belviran Kazası nüfus defterinde şahısların boyları ile ilgili bilgi verilmezken, 1840/41 yıllarına ait defterde ise boy özellikleri kaydedilmiştir. 1840/41 yıllarında Karasınır' da yaşayan 199 erkekten 103 'ünün boy özellikleri belirtilmiştir. Aynı tarihte Elmasun'da yaşayan 132 erkekten oluşmakta iken 62'sinin boylarıyla ilgili bilgi bulunmaktadır.

Grafik 15: Karasınır ve Elmasun'da Yaşayan Erkek Nüfusun Boy Özellikleri, 1840/41.

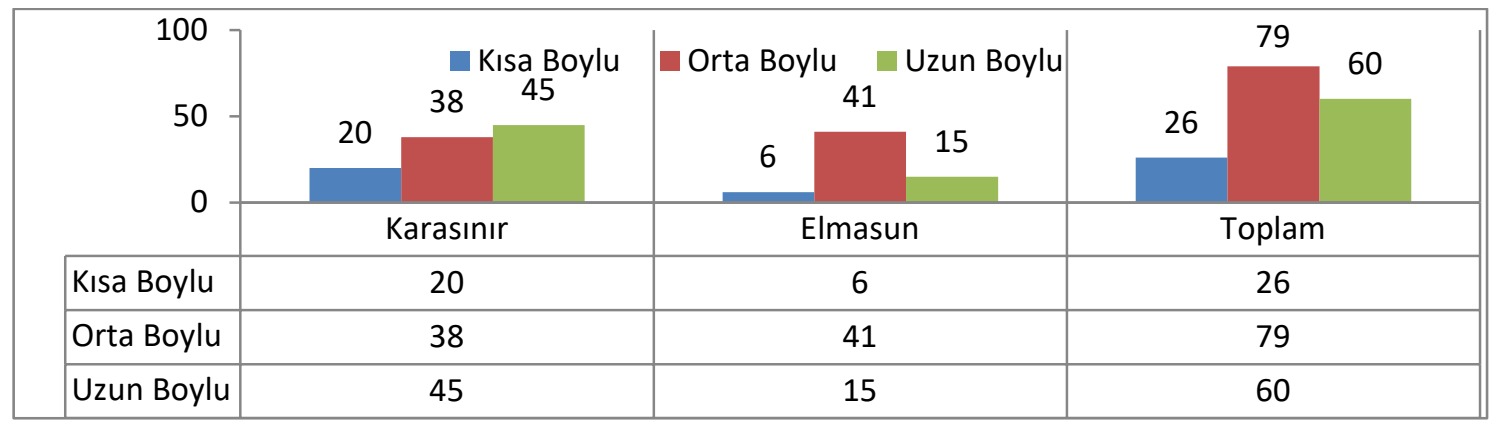

1840/41 yıllarında yapılan nüfus sayımındaki verilere göre Karasınır ve Elmasun'da yaşayan erkeklerin boy oranlarını ortaya koyan grafikler aşağıda verilmiştir. ${ }^{15}$

15 1840/41 yılında Karasınır ve Elmasun'da yaşayan erkeklerin boy oranları için bkz. Grafik 16, 17, 18. 
Grafik 16: Karasınır Köyünde Yaşayanların Boy Oranları, 1840/41.

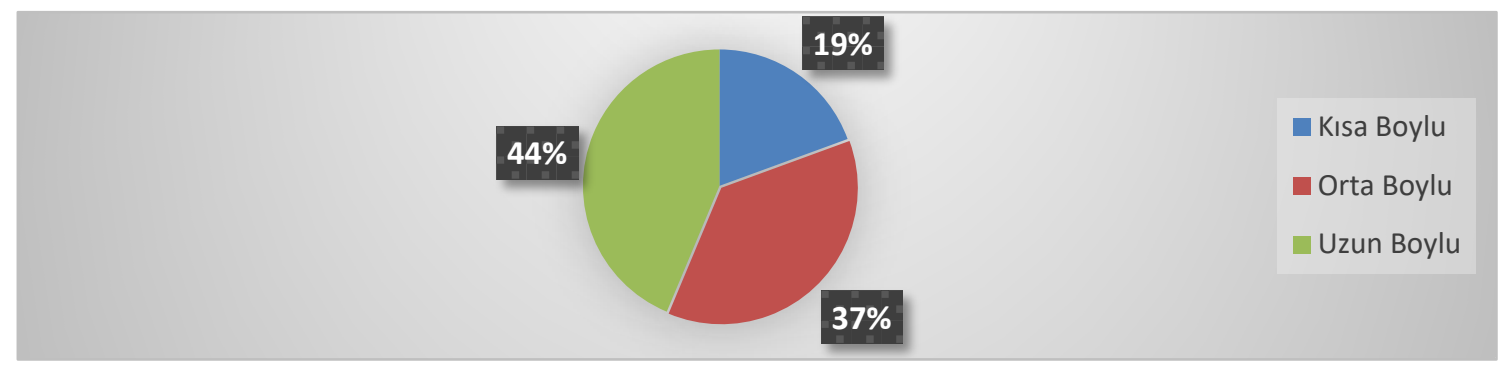

Grafiğe göre Karasınır köyünde \%44 ile çoğunluğun uzun boylu olduğu anlaşılmaktadır. Daha sonra \%37 ile orta boylular gelmektedir. Kısa boylu olarak tasvir edilen kişilerin oranı ise $\% 19^{\prime}$ dur.

Grafik 17: Elmasun Köyünde Yaşayanların Boy Oranları, 1840/41.

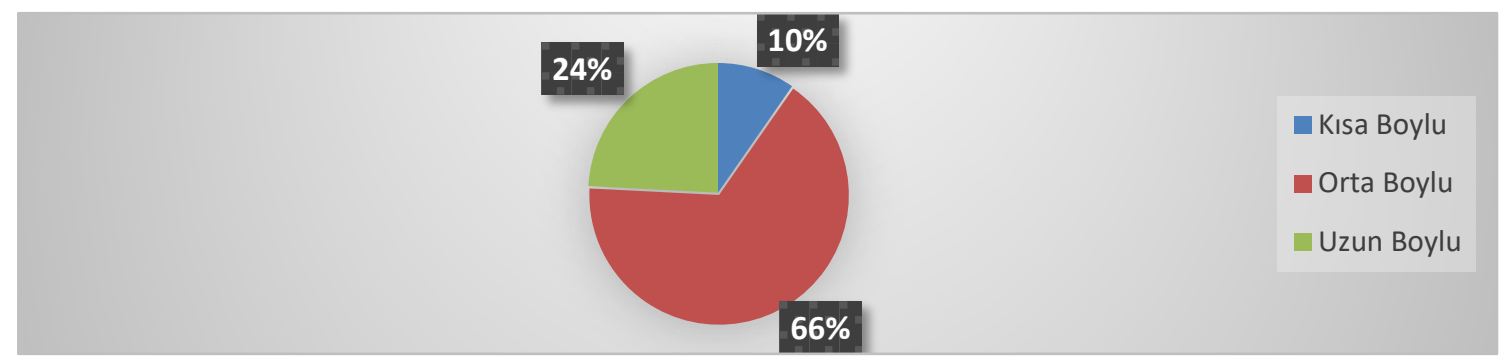

Grafik 16 ve $17^{\prime}$ den anlaşılacağı üzere, Elmasun köyündeki şahısların boy oranları Karasınır'a göre farklı görünmektedir. Elmasun'da, Karasınır'ın aksine \%66 ile köyün genelini orta boylu olarak tasvir edilen kişiler oluşturmaktadır. \%24'ü ise uzun boyludur. Karasınır'da olduğu gibi Elmasun'da da son sırada \%10 ile kısa boylular bulunmaktadır.

İki yerleşimin toplam erkek nüfusunun boy özelliklerine baktığımızda ise çoğunluğu \%48 ile orta boylu grubun oluşturduğunu söyleyebiliriz. Uzun boylular ise \%36 ile köylerdeki büyük bir kesimi oluşturmakta iken, köylerin nüfusunun \%16'sını da kısa boylular oluşturmaktadır. 
Grafik 18: Karasınır ve Elmasun Köylerinde Yaşayanların Boy Oranları, 1840/41.

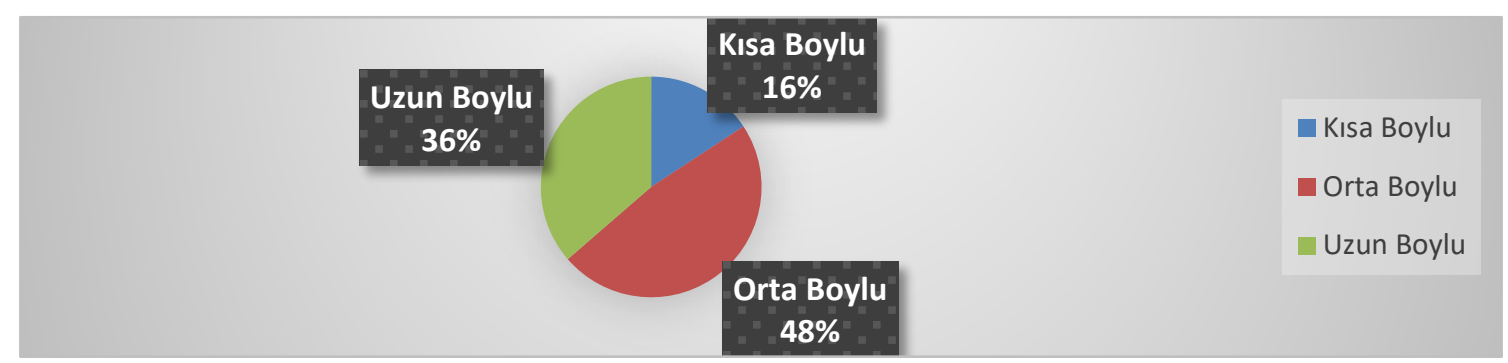

Köylerde yaşayan insanların boyları dışında sakal ve bıyık tanımlamalarından hareketle incelenen yerleşimlerde yaşayan erkeklerin eşkali hakkında da değerlendirmeler yapmak mümkündür. İncelediğimiz defterlerde genellikle 0-10 yaş arasındaki çocukların sakal ve bıyık durumları hakkında doğal olarak herhangi bir veri bulunmamaktadır. 10-20 yaş civarı yaştaki genç erkeklerde ise genel olarak sakal ve bıyık durumları hakkında "şâb emred" veya "ter bıyıklı" gibi ifadeler kullanılmıştır. Dolayısıyla defterlerde genellikle 20 yaş üzerindeki erkeklerin sakal ve bıyık görünümleri hakkında bilgi verilmiştir.

Tablo 1: Karasınır ve Elmasun'da Yaşayanların Sakal ve Bıyık Özellikleri.

\begin{tabular}{|c|c|c|c|}
\hline $\mathbf{1 8 3 4}$ & & $\mathbf{1 8 4 0 / 4 1}$ & \\
\hline Kara Sakallı & 48 & Kara Sakallı & 51 \\
\hline Ak Sakallı & 35 & Ak Sakallı & 27 \\
\hline Kır Sakallı & 23 & Kır Sakallı & 23 \\
\hline Kumral Sakallı & 15 & Kumral Sakallı & 12 \\
\hline Ter Bıyıklı & 8 & Sarı Sakallı & 7 \\
\hline Kara Bıyıklı & 5 & Kara Bıyıkı & 26 \\
\hline Sarı Bıyıkı & 1 & Sarı Bıyıklı & 5 \\
\hline Kart Bıyıklı & 2 & Şâb Emred & 20 \\
\hline & & Ter Bıyıklı & 14 \\
\hline
\end{tabular}

Bu veriler neticesinde köylerde yaşayan şahısların sakal ve bıyık oranları aşağıda grafik olarak verilmiştir. ${ }^{16}$

161834 ve 1840/41 yıllarında Karasınır ve Elmasun'da yaşayan erkeklerin sakal ve bıyık oranları için bkz. Grafik 19, 20. 
Grafik 19: Karasınır ve Elmasun'da Yaşayanların Sakal ve Bıyık Oranları, 1834.

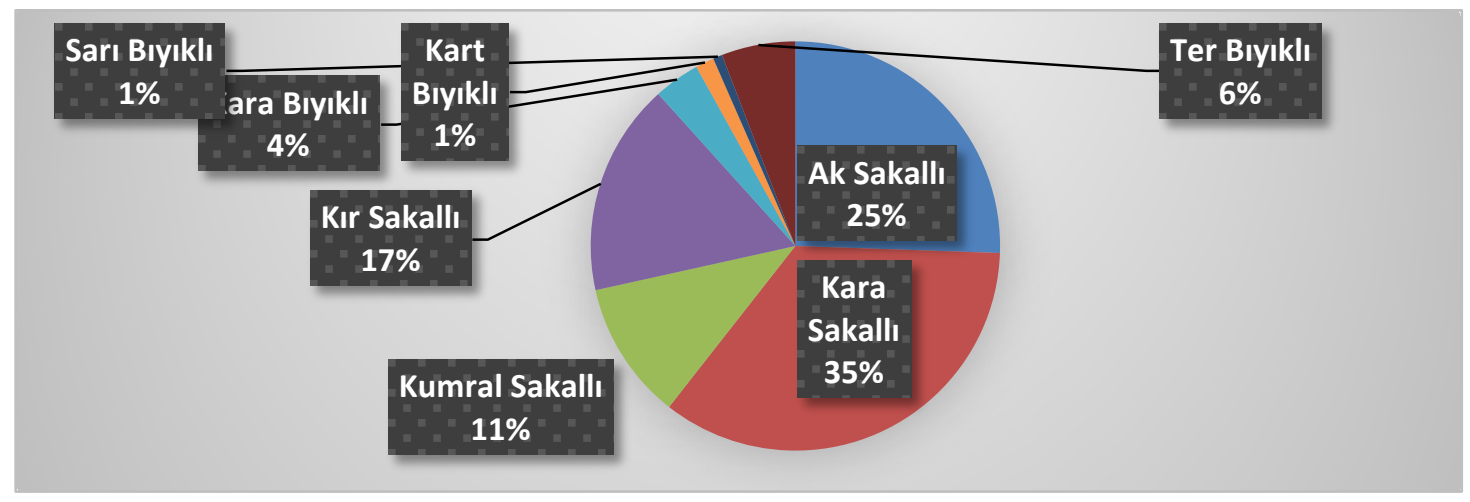

Grafik 20: Karasınır ve Elmasun'da Yaşayanların Sakal ve Bıyık Oranları, 1840/41.

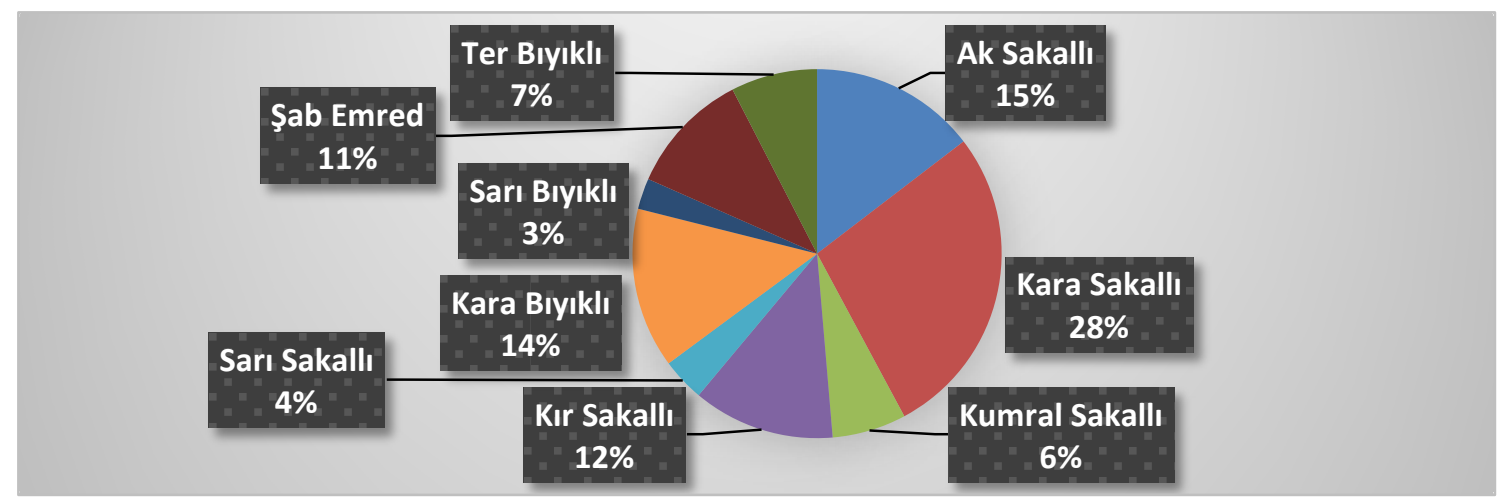

\section{Lakaplar ve Unvanlar}

Soyadı kanunu kabul edilmeden önceki dönemde, ailelerin veya insanların bir çoğu çeşitli lakaplarla anılırlardı. Bu lakapların bir kısmı nesilden nesile devam eden sülale adları iken bir kısmı da kişilerin kendine has özelliklerinden (hastalık, sakatlık, özür, tip, meslek veya memleket) ileri gelirdi. İkinci türden lakapların da bazen nesilden nesile aktarıldığı görülmekle beraber, genellikle kişinin ölümüyle sona ermekteydi (Muşmal-Şahinkaya 2015: 493).

1834 yılına ait nüfus defterleri incelendiğinde, Karasınır ve Elmasun'da yaşayan erkeklerin büyük çoğunluğunun çeşitli lakaplarla anıldıkları anlaşılmaktadır. Kişiler deftere kaydedilirken eğer lakabı sadece kendisi kullanıyorsa kendi isminden önce lakabı belirtilerek (Köse Mehmet, Deli Hasan, Topal Hasan, Gederetli Mustafa gibi) kaydedilmiştir. Eğer kaydedilen kişinin sülalesinden gelen bir lakabı mevcut ise sülale adına oğlu eklenerek (Ruşenoğlu, Derelioğlu, Türkmenoğlu gibi) defterlere kaydedilmiştir. 1840/41 yılına ait defterlerde ise lakaplar belirtilmemiştir. Lakapları incelediğimizde, genellikle şahısların meslekleri, baba isimleri, baba meslekleri ya da memleket isimleri ile anıldıklarını söylemek mümkündür.

1834 ait nüfus defterinde, Karasınır köyüne ait sülale lakapları şunlardır: Paşaoğlu, Ömeroğlu, Hacı Kesekoğlu, Derelioğlu, Eniklioğlu, Türkmenoğlu, Hekimoğlu, Ateşlioğlu, Boduk Kocaoğlu, Seferoğlu, Çakıroğlu, Sağıroğlu, Ruşenoğlu. İkinci türden kişiye özel lakaplar 
ise şunlardır: Çulevli, Zağrak, Şalgacı, Karkaralı, Küçük, Köroğlanın, Dede, Tatar, Ak, Kara, Yörük, Zenci, Topal, Deli.

Elmasun köyünde görülen sülale lakapları ise şunlardır: Zaimoğlu, Hanımoğlu, Cennetoğlu, Türkmenoğlu, Dineklioğlu ${ }^{17}$, Basiroğlu, Odabaşığlu, Madenoğlu, Emir Ömeroğlu, Nebioğlu, Muharremoğlu. İkinci türden kişiye özel lakaplar ise şunlardır: Gök, Ovalı, Dereli, Gederetli ${ }^{18}$, Kara.

Yerleşimlerdeki lakaplar incelendiğinde kişilerin kökenleri hakkında da bir takım bilgiler verildiği görülmektedir. Örneğin; Tatar, Yörük, Zenci gibi lakaplar, kişilerin etnik kökenleri hakkında veriler sağlamaktadır. Ayrıca nüfus defterlerinde kaydedilen erkeklerin bir kısmı isimlerinin yanı sıra çeşitli unvanlarla da anılmışlardır. Bunlar arasında hafız, efendi, hoca, hacı ve molla gibi ifadeler bulunmaktadır. Bu tür unvanlar bölgedeki kişilerin sosyal statülerini yansıtmaktadır. 1834 yılında Karasınır'da 3 kişi hacı, 2 kişi molla, 1 kişi efendi olarak kaydedilmiştir. Elmasun'da ise 2 kişi molla, 2 kişi hoca, 1 kişi efendi olarak kaydedilmiştir.

1840/41 yıllarında ise Karasınır'da 1 kişi efendi, 2 kişi hacı, 1 kişi hafız, 1 kişi molla olarak kaydedilmiş olup Elmasun'da ise sadece 1 kişi efendi olarak kaydedilmiştir. Bu tespitler yalnız sayım defterlerindeki hane reislerine aittir. Bu kişilerin baba isimleri veya meslekleri dikkate alınmamıştır. 1834 ve 1840/41 yıllarına ait Karasınır ve Elmasun köylerinde karşılaşılan sosyal statü ve unvan bildiren kayıtların rakamları aşağıda verilmiştir.

Tablo 2: Karasınır ve Elmasun'da Yaşayanların Sosyal Statü, Unvan ve Dağılımları.

\begin{tabular}{|c|c|c|}
\hline Unvan & $\mathbf{1 8 3 4}$ & $\mathbf{1 8 4 0 / 4 1}$ \\
\hline Efendi & 2 & 2 \\
\hline Hac1 & 3 & 2 \\
\hline Hoca & 2 & 1 \\
\hline Hafiz & & 1 \\
\hline Molla & 4 & \\
\hline Dede & 1 & \\
\hline
\end{tabular}

\section{3. Şahıs İsimleri}

Nüfus defterlerindeki kayıtlarda şahısların kendi isimleri ve baba isimleri yer almaktadır. 1834 yılına ait nüfus defterinde, 182 erkek Karasınır'da, 106 erkek Elmasun'da olmak üzere toplam 288 erkeğin ismi kayıt altına alınmıştır. 1840/41 yıllarına ait defterde ise Karasınır'da 199 kişi ve Elmasun'da da 131 kişi ${ }^{19}$ olmak üzere 330 erkeğin ismi kaydedilmiştir. Bu sayılar içerisine baba isimleri dahil değildir. Sadece hayatta olan kişiler değerlendirmeye alınmıştır.

İsimler üzerinde yaptığımız istatistikî değerlendirmelerde erkek isimlerinden bazıları yoğun olarak kullanılırken, bazı isimlerin ise seyrek kullanıldığı görülmüştür. 1834 sayımında Karasınır'da 182 erkek içinde 37 farklı isim kayıtlıdır. Buna göre köyde en çok kaydedilen isim 24 kişi ile Mehmet'tir. Daha sonra 18 kişi Mustafa, 17 kişi de Ahmet olarak kayıtlıdır. Buna göre 1834 tarihinde Karasınır'da yaşayan erkeklerin \%13,19'unun ismi Mehmet'tir. \%9,89'unun ismi

17 Dinek o dönem Belviran Kazası'na bağlı bir köydür. Günümüzde ise Çumra'ya bağlıdır.

18 Gederet, Belviran Kazası'na bağlı bir köydür. Günümüzde Bozkır'a bağlı Dereiçi Kasabası'nın eski ismi Gederet'tir.

19 Elmasun köyünde 132 kişi bulunmasına rağmen, katip hatasından kaynaklanan bir sebeple hane 30, numara 86'da kişinin baba ismi verilmesine karşın kendi ismi yazılmamıştır. 
Mustafa, \%9,34'ü Ahmet, \%8,79'u Ali'dir. Daha sonra ise \%6,04 ile Hasan ve \%5,49 ile Hüseyin isimleri kayıtlı bulunmaktadır. Aynı tarihte Elmasun köyünde ise 106 erkek içerisinde, Karasınır'da olduğu gibi yine Mehmet ismi 14 kişiyle en çok kullanılan isimdir. Köyde 12 kişinin ismi Ali, 11 kişinin de Mustafa'dır. İki köyde en yaygın isimler benzerlik göstermektedir. Buna göre Elmasun köyünün \%13,21'inin ismi Mehmet'tir. Daha sonra \%11,32 ile Ali, \%10,38 ile Mustafa, \%7,55 ile Abdullah ve yine \%7,55 ile Hasan gelmektedir.

\section{Grafik 21: Karasınır ve Elmasun'da Yaygın Olan İsimler ve Oranları, 1834.}

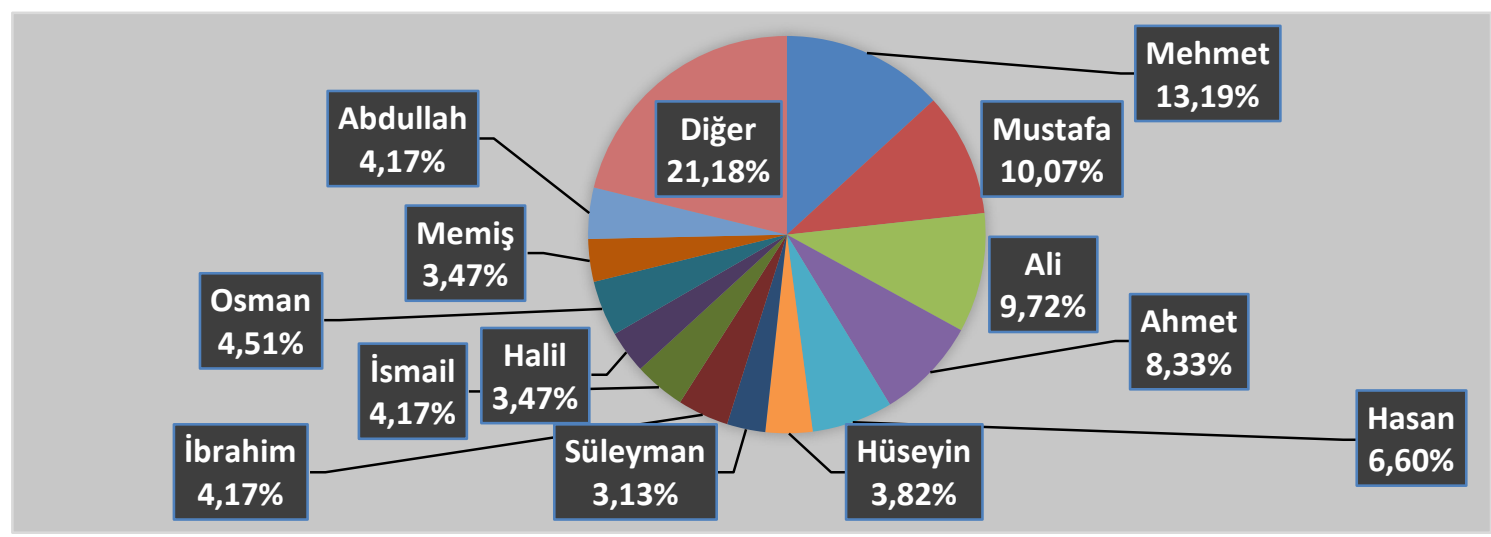

Buna göre 1834 yılında Karasınır ve Elmasun'da erkek isimlerinin en az \%51'i Peygamberimiz Hz. Muhammed (sav), O'nun damadı Hz. Ali ve torunları Hasan ve Hüseyin'in isimleridir. Bu gruba \%4,17 ile İbrahim, yine \%4,17 ile İsmail, \%4,51 ile Osman, \%3,13le Süleyman da dâhil edildiğinde Elmasun ve Karasınır'daki erkeklerin yaklaşık \%68'inin bahsi geçen bu 10 ismi kullandıkları görülmektedir. Buradan hareketle Karasınır ve Elmasun'da yaşayan insanlar arasında Ehl-i Beyt sevgisinin oldukça yaygın olduğu söylenebilir.

1840/41 yıllarındaki sayımda ise Karasınır'da 199 erkekten en çok kaydedilen isim 25 kişi ile yine Mehmet ismidir. Daha sonra 17'şer kişi ile Mustafa ve Ali gelmektedir. Buna göre söz konusu dönemde Karasınır'da yaşayan erkeklerin \%12,44'ü Mehmet, \%8,46'sı Mustafa, \%8,46's1 Ali, \%7,96's1 Ahmet ve yine \%7,96's1 Hüseyin ismi ile kayıtlıdır. Daha sonra ise Memiş, Osman, İbrahim, İsmail, Hasan köydeki yaygın isimlerdir. Aynı tarihte Elmasun'da ise 131 kişiden 19 kişinin ismi Mehmet olup köydeki en çok kaydedilen isimdir. Daha sonra 15 kişi ile Ali ve 14 kişi ile Mustafa ismi gelmektedir. Buna göre 1840/41 tarihinde Elmasun'da yaşayan erkeklerin \%14,50'sinin ismi Mehmet, \%11,45'inin ismi Ali, \%10,69'unun Mustafa ve $\% 9,16$ 'sının ismi Hasan'dır. Daha sonra ise sirasıyla Osman (\%6,87), Abdullah (\%6,87), İbrahim $(\% 6,11)$ isimleri görülmektedir. 
Grafik 22: Karasınır ve Elmasun'da Yaygın Olan İsimler ve Oranları, 1840/41.

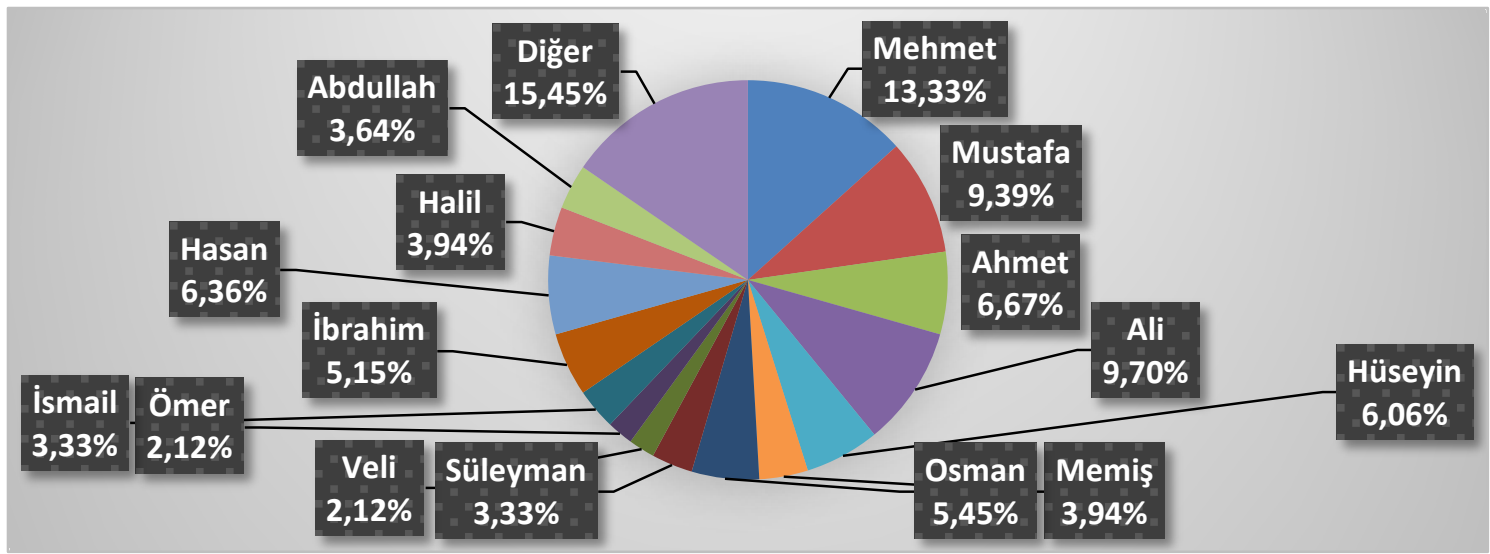

Sonuç olarak ikinci nüfus sayımında da ehl-i beyte ait isimlerin incelediğimiz köylerde yaygın bir şekilde kullanıldığı görülmektedir. Mehmet, Mustafa, Ahmet, Ali, Hasan, Hüseyin, Abdullah gibi bu isimler köylerin büyük bir çoğunluğunu oluşturmaktadır. Nüfus defterlerine göre Karasınır ve Elmasun'da aile reislerinin, çocuklarına kendi isimlerini verdiklerine de rastlanmaktadır. Bundan daha yaygın bir durum ise günümüzde de oldukça sık karşılaştığımız bir gelenek olan çocuklara dede isimlerinin verilmesidir. Bu durumun Karasınır ve Elmasun köylerinde oldukça yaygin olduğu görülmektedir.

\section{SOSYAL YAPI}

\section{Osmanlı Ordusuna Katkı: Askerde Olanlar}

Nüfus defterlerinde kaydedilen bazı kişilerin isim, eşkâl ve yaş bilgileri verildikten sonra isminin sol üst tarafında o kişinin askerde, mansurede ya da redif olduğuna dair kayıtlar düşülmüştür. Ancak bu kayıtlar detaysızdır. Yani kişinin nerede askerde olduğu, hangi tarihte askere gittiği veya kaç yıldır askerde olduğu gibi bilgiler verilmemiştir. Yine de elimizdeki mevcut bilgilerden hareketle Elmasun ve Karasınır'dan Osmanlı ordusuna dahil olanlar ile ilgili bazı bilgiler vermek mümkündür.

1826 yılında kaldırılan Yeniçeri Ocağı'nın yerine Asâkir-i Mansûre-i Muhammediyye isimli ordu kurulmuştur. Osmanlı Devleti'nin belli başlı gelir kaynakları da bu ordu için kurulmuş olan Mansure Hazinesi'ne devredilmiştir. Ancak hazinenin gelirleri ordunun masraflarını karşılamaya yetmediği için askere alınan kişilerin sayısının artırılması mümkün olmamaktaydı. Bunun üzerine başka bir çözüm yolu olarak redif askeri teşkilatı kurulmuştur (Çadırcı 1963: 6667). Redif askeri teşkilatının kurulmasındaki amaç, askerlik çağına gelmiş olan kişileri kendi yaşadığı bölgelerinde az masrafla kısa sürede ve aralıklarla eğiterek savaş anında işe yarayacak yeterli asker bulundurmanın yanı sıra devletin iç güvenliğini de redifler sayesinde sağlamaktı. Böylece fiili olarak askerlik yapanların yanında gerektiğinde silah altına alınabilen bir redif sınıfı da ortaya çıkmıştır (Tunalı 2003: 19).

1834 yılında Karasınır'da 182 kişi içerisinden 7 kişi askerde olarak kayıtlıdır. Aynı tarihte Elmasun'da 106 kişiden 6 kişi askerde olarak kayıtlıdır. Yani toplamda 1834 yılında iki köyde 288 erkek içerisinden 13 kişi askerde bulunmaktadır. 1840/41 yılındaki sayımda ise Karasınır'da 5 kişi mansurede ve 4 kişi de redif olarak kaydedilmiştir. Aynı tarihte Elmasun'da ise 3 kişi mansurede 2 kişi de redif olarak kaydedilmiştir. Yani 1840/41 yılında iki köyde 331 kişiden 8 
kişi mansurede, 6 kişi de redif olarak kaydedilmiştir.

Grafik 23: Köylere Göre Askerde Olanların Dağılımı, 1834.

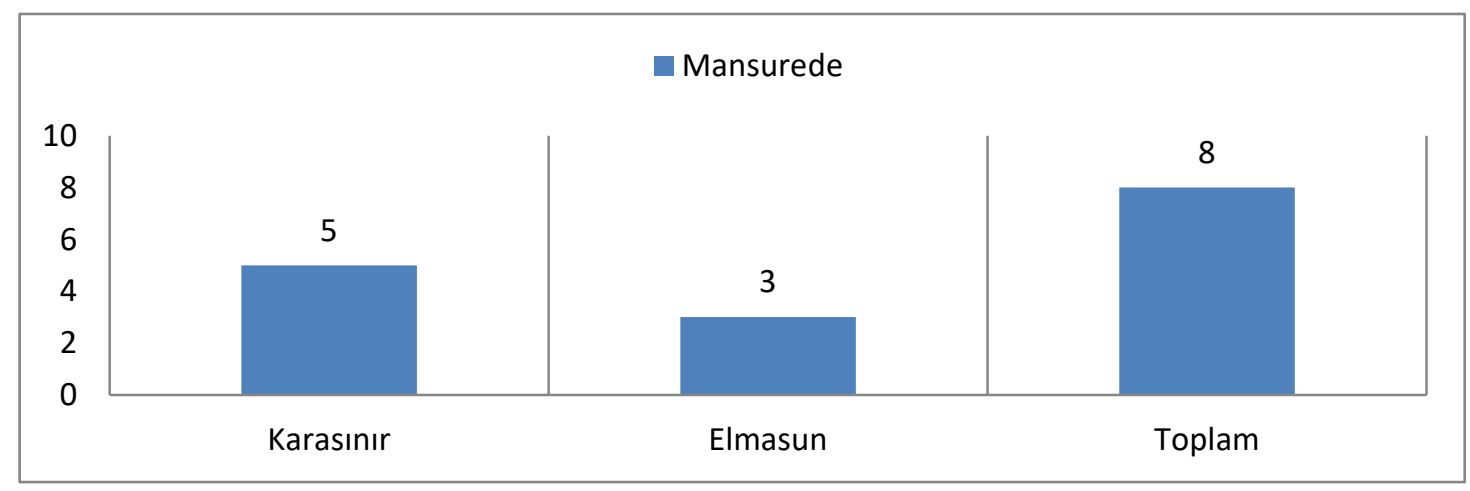

Grafiğe göre, 1834 yılında Karasınır'da bulunan erkek nüfusun \%3,85'i askerlikle ilişkili bulunmaktadır. Aynı tarihte Elmasun'da ise erkek nüfusun $\% 5,66$ 'sının askerlikle ilişiği bulunmaktadır. 1834 yılında iki köyün toplam erkek nüfusunun \%4,51'i asker olarak Osmanlı ordusunda görev yapmaktadır.

Grafik 24: Köylere Göre Askerde Olanların Dağılımı, 1840/41.

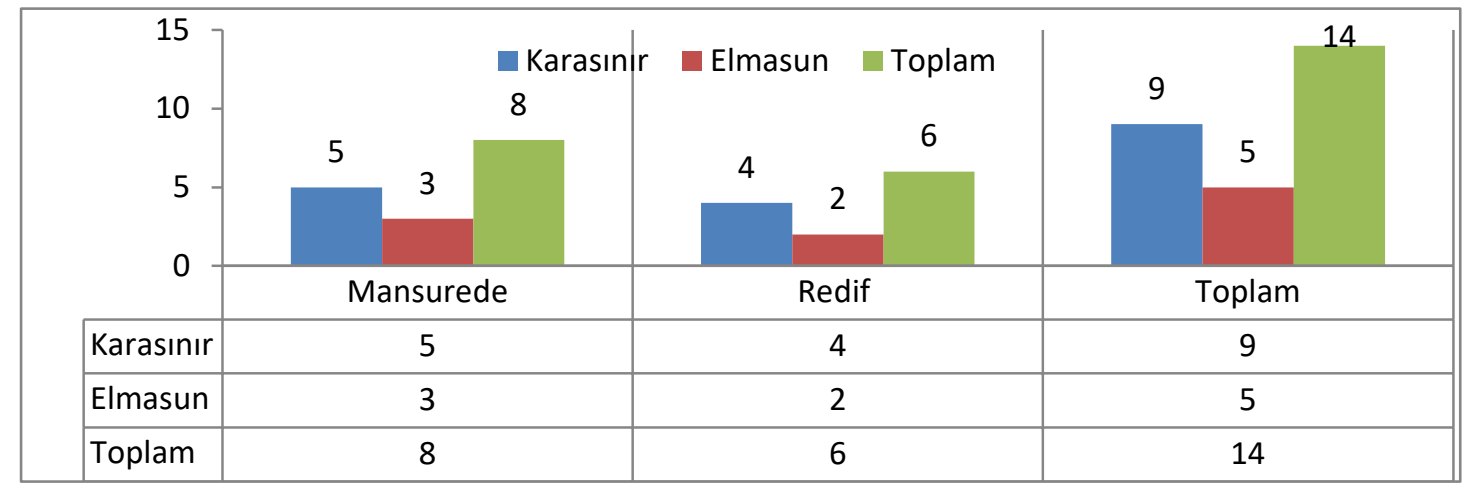

Buna göre 1840/41 yılındaki sayımda Karasınır'da bulunan erkek nüfusun \%4,52'si mansurede ve redif olarak kayıtlıdır. Elmasun'da ise nüfusun \%3,78'i askerlikle uğraşmaktadır. Toplamda 1840/41 yıllarında iki köyün nüfusunun \%4,21'inin askerlik görevini ifa ettiği görülmektedir.

\section{Engel Durumu Olanlar}

Daha önce ifade edildiği gibi bu dönemdeki nüfus sayımlarının temel gerekçesi vergi ve asker toplamak idi. Dolayısıyla nüfus defterlerinde askerlik için uygun olmayan kişilerin engel durumlarıyla ilgili isimlerinin altına kayıtlar düşülmüştür (Muşmal-Şahinkaya 2015: 499). Ancak incelediğimiz defterlerde bu kayitlar genellikle sadece "alil (sakat, hastalıklık)" şeklindedir. Şunu belirtmek gerekir ki engel durumuna ilişkin kayıtlar, incelediğimiz defterlerden sadece 1834 yılına ait nüfus defterinde görülmektedir. 1840/41 yılına ait defterde Elmasun ve Karasınır'da daha önce alil olarak kaydedilmiş kişileri tespit ettiysek de engel durumlarına ilişkin hiçbir kayıt bulunmamaktadır.

Buna göre 1834 yılında Karasınır köyünde 182 kişiden 4 kişi alil olarak kaydedilmiştir. Aynı tarihte Elmasun köyünde ise 1 kişi alil olarak kaydedilmiştir. Yani Karasınır köyünün erkek nüfusunun $\% 2,20$ 'sinin engelli olduğunu anlaşılmaktadır. Elmasun'da ise bu oran \%0,94'tür. 
Köylerdeki engelli kişilerin ortalama yaşı 39,5 olarak ortaya çıkmaktadır.

\section{Tahsilde Olanlar}

İncelediğimiz döneme ait nüfus defterlerinde Elmasun ve Karasınır'da bazı erkeklerin tahsilde olduklarına dair notlar düşülmüştür. Tahsilde olanların nerede ve veya hangi okulda tahsilde oldukları belirtilmemiştir. 1834 yılında Karasınır'da sadece 1 kişi talebe olarak kaydedilmiştir. Elmasun karyesinde ise aynı tarihte 2 kişi talebe olarak kaydedilmiştir. Dolayısıyla 1834 yılında iki köyde toplamda 3 kişi talebedir.

1840/41 yılındaki sayımda ise Karasınır'da 2 kişi tahsilde olarak kaydedilmiştir. Aynı tarihte Elmasun'da ise talebe veya tahsilde şeklinde herhangi bir kayıt bulunmamaktadır. Böylece ikinci sayımda Karasınır'da öğrenim gören kişinin artarken, Elmasun'da hiç kalmadığını söyleyebiliriz. Ancak buna rağmen iki köyün geneline baktığımızda, talebelerin bölgenin genel nüfusu içerisindeki oranın çok az olduğu sonucu çıarılabilir.

\section{Köleler ve Hizmetçiler}

İncelediğimiz nüfus defterlerinde bazı hanelerde aile üyelerinin sonunda erkek kölelerin de kaydedildiği görülmektedir. 1834 yılında Karasınır'da iki kişi gulam (köle) olarak kaydedilmiştir. Aynı kişiler 1840/41 yılı sayımında da kayıtlarda bulunmaktadır. Elmasun'da ise iki sayımda da gulam bulunmadığı görülmektedir.

Karasınır'da her iki sayımda da kölelerden birincisi hane 2'de Zenci Reyhan veled-i Abdullah olarak kayıtlı olan köledir. Köydeki kayıtlı olan ikinci köle ise hane reisi olarak kaydedilmiştir. Hane reisinin adı ve baba adı gulam (gulam veled-i gulam) olarak kaydedilmiş olup, Abdullah, Ahmet, Osman adında üç erkek çocuğu olduğu görülmektedir. İlk sayımda Ahmet isimli bir kişi, Gulam isimli hane reisinin babalığı olarak kaydedilmiştir. İkinci sayımda ise bu kişi muhtemelen vefatından dolayı kayıtlarda yer almamaktadır.

\section{SONUÇ}

Nüfus defterleri, nüfusun tespiti, Osmanlı Devleti'ndeki aile yapısının ortaya çıkartılmasında, ortalama çocuk sayısı ve yaş aralıkları, doğum ve ölüm oranları gibi konuların tespitinde çok önemli veriler sunmaktadır. Ayrıca bu yönüyle aynı dönemde tutulmuş temettuat defterlerinin bu noktadaki eksikliğini de ortadan kaldırmaktadır.

Çalışmamızın tespitlerinden birisi Karasınır ve Elmasun'da 1834 yılında yaklaşık 600 kişi civarında bir nüfus bulunduğudur. 1840/41 yılında ise bu sayı yaklaşık 670 civarına yükselmiş olduğu görülmektedir. Bütün bu sorgulamaların sonunda bu çalışmanın belirgin sonucu olarak Karasınır ve Elmasun köylerinde yaşayan insanların arasında çekirdek aile yapısının hâkim olduğu, kadının doğum yapma sayısı ortalama çocuk sayısından şüphesiz yüksek olmakla birlikte ortalama çocuk sayısının yaklaşık 3 civarında olduğu tespit edilmiştir. Bu durum daha önce yapılan çalışmalarda klasik dönem Osmanlı toplumu da dâhil olmak üzere sürekli tekrarlanagelen Osmanlı ailesinin 3 çocuk ve 1 anne-babadan oluşan çekirdek aileye sahip olduğu tespitinden ve onu tekrarlamaktan öteye geçememiştir. Bu yönüyle elde edilen veriler bir tekrar ve teyitten ibarettir. Ancak en azından Karasınır ve Elmasun ölçeği için nüfusun yaş dağılımına göre oldukça genç bir nüfus olduğu yeni bir tespit olarak söylenebilir. Elmasun ve Karasınır'da yaşayan erkeklerin 1834 yılında ortalama yaşı 24,3, 1840-41 yılında ise 23'tür. Yani aslında Osmanlı Devleti'nin bu sayımdan beklentilerine büyük oranda Karasınır ve Elmasun köyleri pozitif bir cevap vermektedir. Kazadaki erkeklerin yaklaşık \%5'i sayımlar sırasında hala 
askerdedir ve askerde olmayan gençlerin önemli bir yekûn tuttuğu da bu defter vasıtasıyla kayıt altına alınmış olmalıdır.

Günümüz Türkiye toplumuyla önemli ölçüde benzerlik gösteren kimi tespitler ise, bazı şahıs isimlerinin kullanım sıklığı ve yaygınlığıyla alakalı olanıdır. Her iki sayımda da Karasınır ve Elmasun'da yaşayan yaklaşık olarak her yedi kişiden birinin ismi Mehmet olduğu görülmektedir. Her 5 erkekten birinin ismi Mustafa ya da Ali'dir. Her sekiz erkekten birinin ismi Hasan ya da Hüseyin'dir. Dolayısıyla iki köyde Mehmet, Mustafa, Ali, Ahmet, Hasan, Hüseyin isimlerinin en yaygın kullanılan isimler olduğu tespit edilmiştir. Ayrıca insanların kendi babalarının isimlerini, kendi çocuklarına verme eğilimde oldukları net olarak anlaşılmakla birlikte Karasınır ve Elmasun'da ortaya çıan bu oran Ehl-i Beyt sevgisinin oldukça yaygın ve güçlü olduğunu kanaatini de uyandırmaktadır.

Kişilerin boy tanımlamalarının sayım memurları tarafından hangi ölçeğe göre yapılmış olduğu şimdilik tarafımızca malum değildir. Eğer günümüz toplumundaki değerler o dönemde de geçerli ise göz kararı ya da genel fiziki görünümün altında ya da üstünde oluşa göre kişiler orta, uzun veya kısa boylu olarak tanımlanmışlardır. İncelediğimiz defterlerde 1834 yılında kişilerin boylarına ilişkin herhangi bir kayıt olmamakla birlikte 1840/41 yılına ait deftere göre köylerdeki yaklaşık olarak her iki kişiden birisi orta boyludur. Kısa boyluların oranı \%16 civarında iken uzun boyluların oranı \%36 olması dikkat çekicidir. Ayrıca sadece Karasınır'da uzun boylu olarak kaydedilen kişiler \%44 oranla köyün en kalabalık kesimini oluşturmaktadır. Köyün \%37'si ise orta boylu, \%19'u da kısa boylu olarak kaydedilmiştir.

Karasınır ve Elmasun bölgesinde iki sayım toplamında sadece bir kişinin dışarıya göç ettiği görülmektedir. Başka bölgelere çok fazla göç yaşanmamasının sebebi, bölgedeki arazinin, sınaî ve ticarî faaliyetlerin orada yaşayan insanların geçimine yeterli ve sağlık koşullarının sair bölgelere göre daha iyi olmasından kaynaklanmış olabilir.

İncelediğimiz 1834 yılına ait nüfus defterine göre bazı insanlar, alil (sakat) olarak tanımlanmışlardır. Bunların oranı Karasınır ve Elmasun'da \%1,7'dir. 1840/41 yılındaki defterde aynı kişiler tespit edilmesine rağmen engel durumlarına ilişkin not düşülmemiştir. Günümüz Türkiye toplumuna özürlü oranının \%9-10 civarında olduğu düşünülürse bu orandaki bir seviye oldukça düşük görünmektedir. Ancak günümüz toplumundaki özürlü anlayışının XIX. yüzyılın ortalarında geçerli olmadığı düşünülürse, insanların hayatta kalma oranının daha düşük olduğu da göz önüne alınırsa bu oran daha az şaşırtıcı olacaktır. Osmanlı toplumunda kölelik XIX. yüzyıla kadar tedricen azalmakta ise de bu tarihlerde incelediğimiz köylerden Karasınır'da sosyal ve ekonomik durumu iyi olanlar arasında az da olsa devam etmektedir. Karasınır'da gulam olduğu belirtilen 2 kişi kaydedilmiştir. İki sayımda da aynı iki şahıs gulam kaydedilmiştir. Elmasun köyünde ise sayımlarda herhangi bir gulam kaydı bulunmamaktadır.

\section{SUMMARY}

In our study, Karasinir and Elmasun villages have been investigated from the aspect of the population censuses carried out in Ottoman State in the years of 1834 and 1840/41. Today, Karasinir and Elmasun (Guneybag) are the central neighborhoods of Southernborder district of Konya province. These two settlements were the villages, associated with Belviran district of Konya Flag of Karaman Province, with the same names during the Ottoman period.

The population book dated February 27, 1834 (H. 17 Shawwal 1249), of Belviran district, Karasinir and Elmasun villages are associated with, is registered in the BOA, NFS.d, catalog , numbered 3373 at Prime Ministry, Department of Ottoman Archives, General Directorate of 
State Archives .The book consists of 67 pages in total. The information of Elmasun village's population and household are registered between numbered 47 and 48 pages. The population and household information of Karasinir village are included between numbered 49 and 52 pages. The names, father names, nicknames, ages, and appearance information of the registered male have been included in the population books concerning the years of 1834 and $1840 / 41$, two archival sources of our study. There is no record of female population in the books. According to the records in the population book dated 1834, there are 182 male in 62 households in Karasinir village and 106 male in 42 households in Elmasun village.Accordingly, it can be said that the total population of two villages in 1834 is approximately 576 people. The families living in the villages were seen intensively to have core family characteristics. It is seen as a result of population censuses that only one person emigrated from these two villages. The reason why there was not much migration outside Karasinir and Elmasun villages might be due to the fact that land, living and health conditions in the region were better than other regions'.

In the 1834 census, the average age of these two villages was 24.3 years. The ratio of children ( 0 to 10 ) is seen $35.77 \%$,that of young (11 to 30 ) $28.47 \%$,that of middle aged (31 to 50 ) $24.09 \%$, that of aged people (50 to 100 ) $11.68 \%$. From this point of view, and considering that average age is 24.3 tears, it can be said that Karasinir and Elmasun villages sinificantly have young population, and that because of the fact that the ratio of those people above 50 years old is very low, the average life span is considerably low.

The names of persons and their father names are included in the records of the population books. According to this, in 1834, the name of Prophet Muhammad (sav), of Ali, Prophet Muhammad's son-in-law, and of Hasan and Hussein, Prophet Muhammad's grandsons were given to at least $51 \%$ of the male in Karasinir and Elmasun villages. When the names of İbrahim with $4.17 \%$ İsmail with $4.51 \%$,Osman with $4.51 \%$ and Süleyman with $3.13 \%$ are added in this group, it is seen that approximately $68 \%$ of male in Elmasun and Karasinir used these 10 names. From this point of view, it can be said that the love of Ehl-i -i Beyt was very common among the people living in Karasinir and Elmasun.

According to the books examined, 13 of totally 288 men in these two villages had joined the army in 1834. In addition to this, 2,20\% of the male population in Karasinir and 0,94\% of that in Elmasu were determined as unable to do military service for being disabled in 1834. In 1834, only 1 person is registered as a student in Karasinir., 2 people in Elmasun are registered as students.That is, three people in these two villages are registered as students in 1834. Two people are registered as gulam (slave) in Karasinir in 1834. The same persons are also on record in the 1840/41 census. It is seen that there is no gulam in both population censuses.

The population book of Belviran district, which is the second archival source of our study, concerning H. 1256 (1840-41) year is registered in the BOA, NFS.d, catalog, numbered 3374 at Department of Ottoman Archives. The book consists of 224 pages. The population and household information of Karasinir village are included between numbered 198 and 208 pages. The population and household information of Elmasun village, registed right after, are between numbered 209 to 215 pages.

According to the population book, number 3374 dated 1840-41, there are 199 male in 55 households in Karasinir village, and 132 male in 47 households in Elmasun. village. According to the population census dated 1834, the population of Karasinir village is seen to 
increase by 17 people. The male population in Elmasun is seen to increase from 106 to 132.Considering that the female population was as much as the male population, when the male population is multiplied by two, it is concluded that the approximate total population of wo villages increased by 86 persons, compared to the previous census, thus yielding to 662 persons.Regarding average age, the average age of two villages decreased from 24.3 to 23 . Moreover, it can be said that the ratio of large family in Elmasun and Karasinir was at least about $39 \%$ in $1840 / 41$. This situation seems appropriate for the core family structure, which is the dominant type of the Ottoman family.

While no information is given about the heights of persons in the population book corcerning 1834, the heights of those are given in the book corcerning 1840/41 years. When we investigate the height characteristics of total male population of two settlements, we can see that the majority is composed of medium height people. Tall people constituted a large part of the population in these villages, with the ratio of $36 \%$; while $16 \%$ of these villages' population were of short people.

8 of 331 people in these two villages are registered as at mansura, 6 of those as redif in 1840/41 Accordingly, it is seen that $4,21 \%$ of two villages' population performed military service. Two people were recorded as students in Karasinir village. There is no student record in Elmasun at the same date. Accordingly, when we take two villages into consideration in general, it can be said that the ratio of students in general population of the region was very low. 


\section{KAYNAKÇA}

\section{Arşiv Belgeleri}

T.C. Başbakanlık Osmanlı Arşivi, (BOA), NFS.d nr. 3373. (1249.Ş.17 Tarihli Belviran Kazası Nüfus Defteri)

T.C. Başbakanlık Osmanlı Arşivi, (BOA), NFS.d nr. 3374. (1256 Tarihli Belviran Kazası Nüfus Defteri)

\section{Diğer Kaynaklar}

"130 İlçe Kurulması Hakkında Kanun", T. C.Resmi Gazete, S. 20523, 20.05.1990.

AKANDERE, Osman (1998), “Konya Vilayeti Salnamelerine Göre 1864-1904 Yılları Arasında Konya Sancağının İdari Yapısı", İpek Yolu Konya Ticaret Odası Dergisi, Özel Sayı I: 99-130.

AKYEL, Salih, Savaş Sertel (2015, December), "Osmanlı Nüfus Defterlerinin Tarih Yazımındaki Yeri: 1840 Tarihli Çarsancak Kazası Gayrimüslim Nüfus Defteri Örneği", Journal of History and Future, C. I, S. 1: 78-98.

BEHAR, Cem (2000), "Osmanlı Nüfus İstatistikleri ve 1831 Sonrası Modernleşmesi", Osmanlı Devleti'nde Bilgi ve İstatistik, Ankara: T.C. Başbakanlık Devlet İstatistik Enstitüsü, 61-72.

BOZKURT, Nebi (2007), “Nüfus”, Diyanet İslam Ansiklopedisi, XXXIII, İstanbul: Tarih Vakfı Yurt Yayınları: 293-300.

ÇADIRCI, Musa (1963), "Anadolu'da Redif Askerî Teşkilatının Kuruluşu", Ankara Üniversitesi Dil ve Tarih, Coğrafya Fakültesi Tarih Araştırmaları Dergisi, C.VIII, S.14: 63-75.

ÇiMEN, Adnan (2012), "Sayım, Kayıt Düzeni ve Teşkilatlanma Açısından Osmanlı'da Nüfus Hizmetleri", Gazi Üniversitesi İktisadi ve İdari Bilimler Fakültesi Dergisi, 14/3: 183-216.

DEVELLiOĞLU, Ferit (2000), Osmanlıca-Türkçe Ansiklopedik Lugat, 17. Baskı, Ankara: Aydın Kitabevi.

GÜL, Abdülkadir (2015), “Son Dönem Osmanlı Eğin Nüfus Defterleri ve Bize Sundukları”, AKRA Kültür Sanat ve Edebiyat Dergisi, III, S. 7: 155-173.

GÜL, Muammer, Atilla Bayram, Oğuzhan Hakkoymaz (2003), Selçuklu'dan Günümüze Konya'nın Sosyo-politik Yapısl, Konya: Konya İl Emniyet Müdürlüğü AR-GE Yayınları.

Güneysınır Belediyesi Resmi Web Sitesi, "Tarihçe", Erişim Tarihi: 01.02.2018, http://www.guneysinir.bel.tr/icerik/tarihi.html.

GÜRTAN, Kenan (1969), Demografik Analiz Metotları, İstanbul: Sermet Matbaası.

KARAL, Enver Ziya (1997), Osmanlı İmparatorluğu'nda İlk Nüfus Sayımı 1831, II. Baskı, Ankara: T.C. Başbakanlık Devlet İstatistik Enstitüsü.

KARPAT, Kemal H. (2003), Osmanl Nüfusu (1830-1914) Demografik ve Sosyal Özellikleri, çev. Bahar Tirnakc1, İstanbul: Tarih Vakfı Yurt Yayınları.

KÜÇÜKDAĞ, Yusuf (1996), Armutlu, Konya: Armutlu Köyü Kuran Kursu Derneği.

KÜTÜKOĞLU, Mübahat (2010), Menteşe Sancă̆ı 1830 (Nüfus ve Toplum Yapısı), Ankara: Türk Tarih Kurumu Basımevi.

Mevlana Kalkınma Ajansı (2014), Güneysınır İlçe Raporu, Konya.

MUŞMAL, Hüseyin (2006), "XIX. Yüzyıl Ortalarında Beyşehir Bölgesinden İzmir ve İstanbul'a Yapılan Göçler", I. Uluslarası Beyşehir ve Yöresi Sempozyumu Bildiriler Kitabı, 11-13 Mayıs 2006, Konya: 269-284.

MUȘMAL, Hüseyin (2015), "1844 Tarihli Nüfus Sayımına Göre Beyșehir Kazası”, Turkish Studies International Periodical For The Languages, Literature and History of Turkish or Turkic, Volume 10/1, 477-510.

MUŞMAL, Hüseyin, Bayram Ürekli, “Tanzimat Döneminde Konya'da Faaliyet Gösteren Yabancı Esnaflar ve Tüccarlar", Yayınlanmamış Makale.

ÖZ, Mehmet (2000), "Tahrir Defterlerindeki Sayısal Veriler", Osmanl Devleti'nde Bilgi ve İstatistik, derleyenler Halil İnalckk-Şevket Pamuk, Ankara: T.C. Başbakanlık Devlet İstatistik Enstitüsü, 15-32.

SILAY, Güler (2015), Belviran Kazası Tarihçesi ve Sosyokültürel Yapısı, Konya: Çizgi Kitabevi.

ŞAFAKÇI, Hamit (2016), “Belviran Kazası Tekke ve Zaviyeleri”, Vakıflar Dergisi, S. 45: 59-89. 
T.C. Konya Valiliği İl Kültür Müdürlüğü (1999), Milli Mücadeleden Günümüze Konya (1915-1965), C. I, Konya: Arı Ofset Matbaacilık.

TUNALI, Ayten Can (2003), Tanzimat Döneminde Osmanlı Kara Ordusunda Yapılanma (1839-1876), Ankara: Ankara Üniversitesi Sosyal Bilimler Enstitüsü: (Doktora Tezi).

USLUCAN, Cihat (2012), 19. Yüzyılın İlk Yarısında Samsun Kazası'nın Nüfusu, Samsun: Ondokuzmayıs Üniversitesi Sosyal Bilimler Enstitüsü: (Yüksek Lisans Tezi) 
EKLER

Belge 1: 3373 Numaralı Belviran Kazası Nüfus Defterinin Kapak Sayfası, 1834.

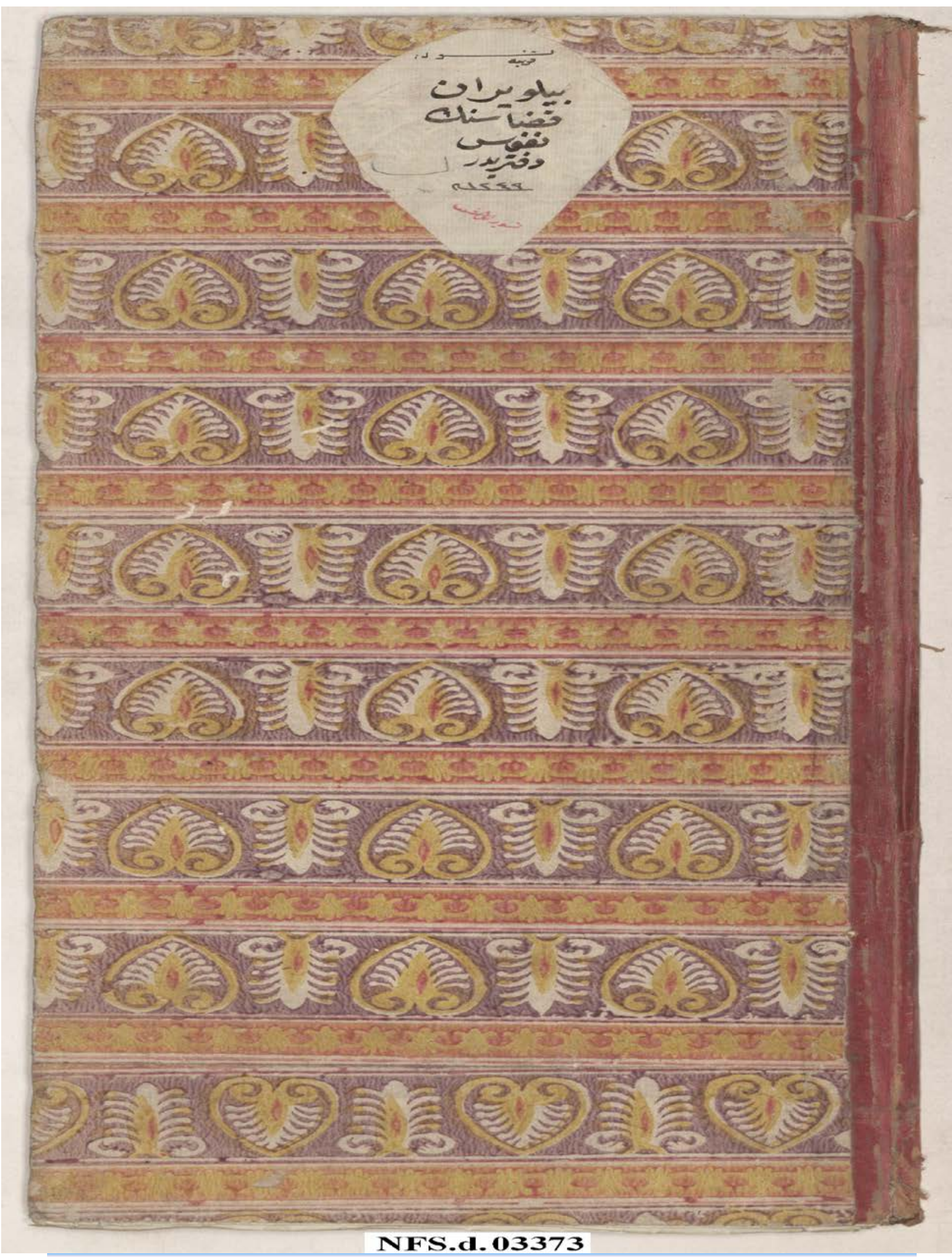


Belge 2: 3373 Numaralı Belviran Kazası Nüfus Defterinde Elmasun Köyü, 1834.

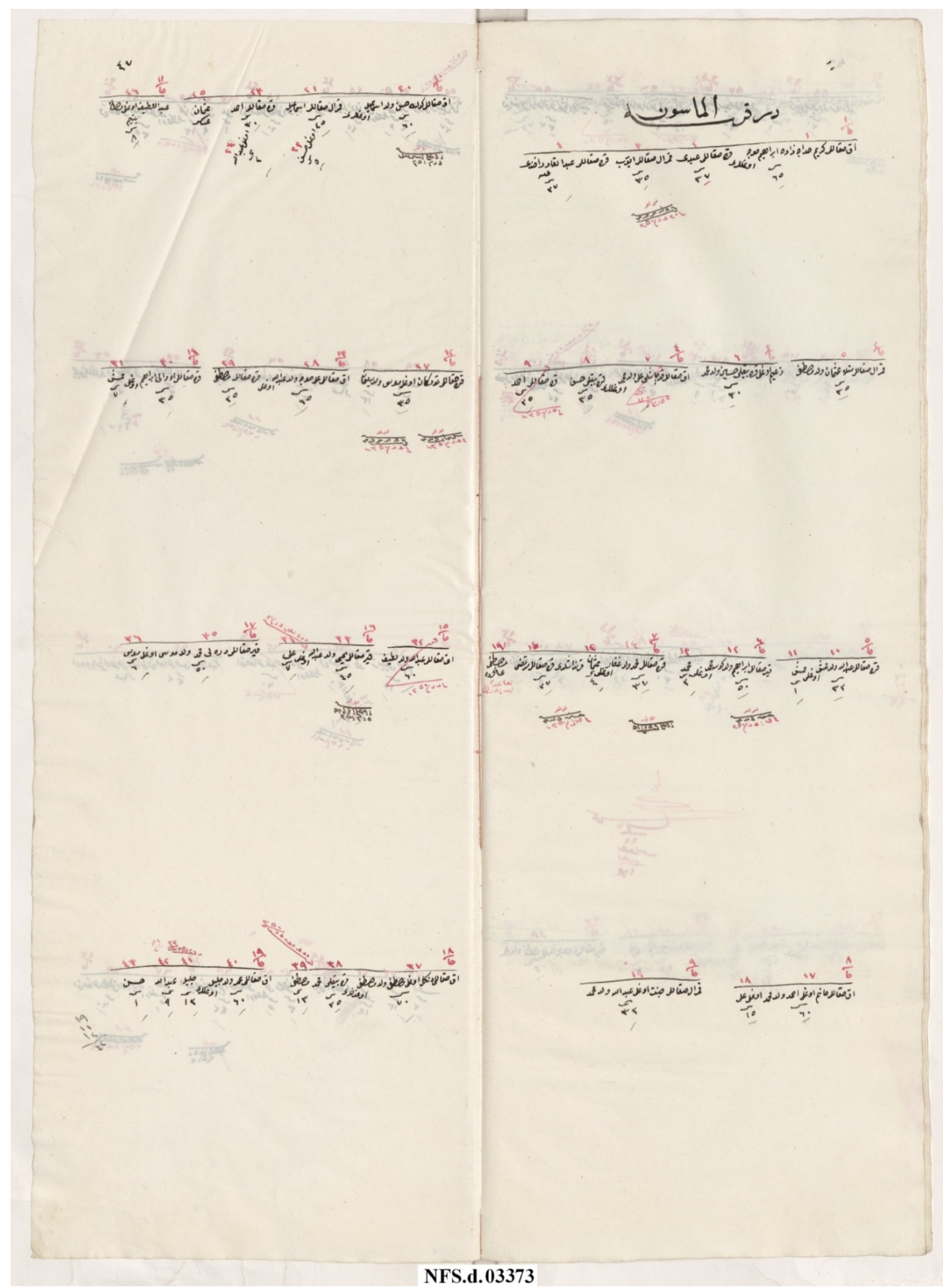


Belge 3: 3374 Numaralı Belviran Kazası Nüfus Defterinde Karasınır Köyü, 1840/41

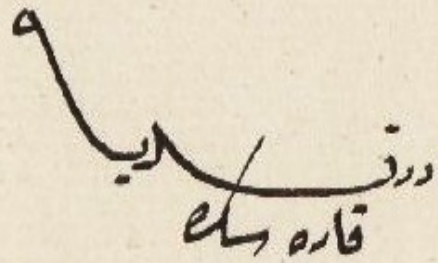

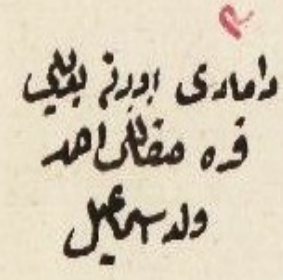

$\sim 0$

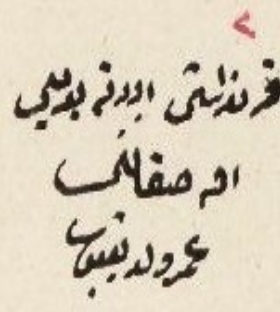

$\checkmark$

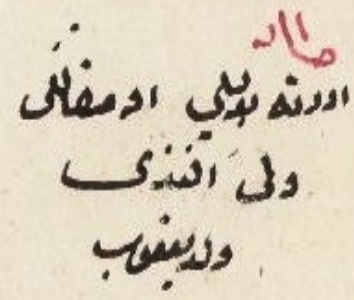

01

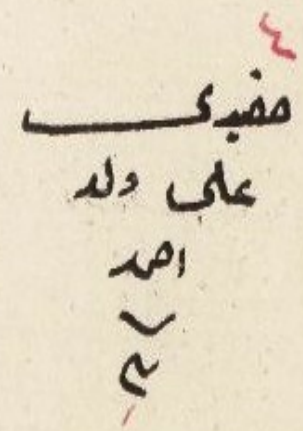

ite
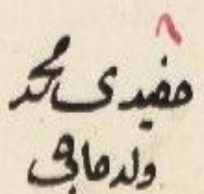

2.1

$\checkmark$<smiles>[AlH2]</smiles>

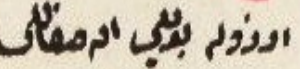

-

ولدة

V.

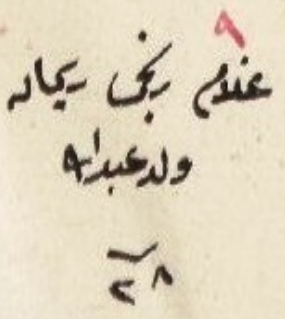

1 